\title{
En uygun rüzgâr enerji santrali yerlerinin coğrafi bilgi sistemleri ile belirlenmesi: Kocaeli ili örneği
}

\author{
Serdar Ekiz ${ }^{*}$ (I) , Ahmet Şirin ${ }^{1}$ (D), Arzu Erener ${ }^{1}$ (D) \\ ${ }^{1}$ Kocaeli Üniversitesi, Mühendislik Fakültesi, Harita Mühendisliği Bölümü, İzmit, Kocaeli, Türkiye.
}

Öz: Insanlar yaşamları boyunca, birçok gereksinimlerini yerine getirmek için enerjiye ihtiyaç duymuşlardır. Bu ihtiyacı karşılayabilmek için ise, öncelikle enerjinin üretimi ve buna paralel olarak enerjinin üretileceği alanların tespiti önem kazanmıştır. Bu çalışmada, yenilenebilir enerji kaynaklarından biri olan rüzgâr enerjisini kullanarak, elektrik enerjisi elde eden rüzgâr enerji santrallerinin (RES) inşası için, Coğrafi Bilgi Sistemleri (CBS) ortamında çeşitli faktörler dikkate alınarak en uygun yer araştırması yapılmıştır. İlk olarak, geçmişte yapılan benzer çalışmalardan yola çıkılarak, RES yer seçimi sürecinde etkisi bulunan 13 faktör belirlenmiştir. Bunlar; rüzgâr hızı, korunan alanlar, kuş göç yollarl, trafo merkezleri, enerji nakil hatları, yerleşim alanları, karayolları, fay hatları, yükseklik, eğim, akarsular, göller ve havaalanlarıdır. Belirlenen bu faktörler kendi içlerinde, 0 (uygun değil) - 5 (son derece uygun) arasında olmak üzere 6 puan sınıfina ayrılmıştır. Daha sonra, RES için uygun olmayan puan sinıfinda (0) bulunan alanlar, diğer puan sınıfindaki alanlardan ayrıştırılarak bir maske alanı haritası oluşturulmuştur. Elde edilen maske alanı haritası ile, RES için uygun olan ve olmayan alanlar net bir şekilde belirlenmiştir. Uygun olan alanların, uygunluk derecelerine göre sinıflandırllabilmesi için ise ağırlıklı çakıştırma yöntemi kullanılmıştır. Ağırlıklı çakıştırma yöntemi uygulanırken, faktörlerin birbirlerine göre ağırlıkları 2 farklı şekilde belirlenmiştir. Illk çalışmada, Çok Kriterli Karar Analizi (ÇKKA) yöntemlerinden biri olan Analitik Hiyerarşi Yöntemi (AHY) kullanılarak faktörler ă̆ırlıklandırılmış ve üst üste çakıştırma analizi yapılmıştır. İkinci çalışmada ise, ağırlıkl çakıştırma analizi faktörler eşit ağırlıkta kabul edilerek uygulanmıştır. İki farklı analiz sonucunda elde edilen haritalar, maskeleme alanı ile örtüştürülerek, Kocaeli için RES uygunluk haritaları elde edilmiştir. Elde edilen sonuç uygunluk haritaları üzerinden, uygunluk sınıfları için alan hesaplamaları yapılmış ve iki yöntem birbirleriyle karşılaştırılmıştır. Sonuç olarak, Kocaeli ilinin tamamı üzerinde yapılan bu çalışmada CBS ve AHY kullanılarak, RES kurulabilecek en uygun alanlar tespit edilmiştir.

Anahtar Sözcükler: CBS, Rüzgâr enerji santrali, En uygun yer seçimi, Çok kriterli karar analizi, AHY, Kocaeli

\section{Determination of the most suitable wind power plant locations with geographical information systems: Kocaeli province example}

\begin{abstract}
In their lifetime, people need the energy to fulfill their needs. Beforehand, production of energy and, in parallel, the determination of the areas where the energy will be produced has gained importance. In this study, the most suitable site research was carried out in the Geographic Information Systems (GIS) for the construction of wind power plants (WPP) for the environment. It obtains electrical energy by using wind energy, which is one of the renewable energy sources. First of all, 13 factors that have an impact on the WPP site selection process were determined based on similar studies conducted in the past, these are; wind speed, protected areas, bird migration routes, transformer centers, power transmission lines, residential areas, highways, fault lines, elevation, slope, streams, lakes and airports. These determined factors are divided into 6 score classes, ranging from 0 (not suitable) to 5 (extremely appropriate). Then, a mask area map was created by separating the areas in the score class (0) not suitable for WPP from the areas in the other score class. With the mask area map obtained, suitable and unsuitable areas for WPP were clearly determined. The weighted overlay method was used to classify the suitable areas according to their degree of suitability. While applying the weighted overlay method, the weights of the factors with respect to each other were determined in two different ways. In the first study, the factors were weighted and overlapping analysis was performed by using the Analytical Hierarchy Process (AHP), which is one of the Multi-Criteria Decision Analysis (MCDA) methods. In the second study, weighted overlapping analysis was applied by accepting the factors as equally weighted. By overlapping the maps obtained as a result of two different analyzes with the masking area, WPP suitability maps for Kocaeli were obtained. Area calculations were made for the suitability classes over the resulting suitability maps and the two methods were compared with each other. As a result of this study, which was carried out on the entire province of Kocaeli, the most suitable areas where WPP could be established were determined by using GIS and AHP.
\end{abstract}

Keywords: GIS, Wind power plants, The most suitable location selection, Multi-criteria decision analysis, AHP, Kocaeli 


\section{Giriş}

Dünya nüfusunun artması sonucunda enerji kaynakları konusunda büyük bir arz ve talep oluşmakta ve birinci elden kullanılabilen enerji kaynakları gün geçtikçe tükenmektedir. Bu durum diğer dünya ülkelerini olduğu gibi, ülkemizi de enerji üretimi konusunda farklı yollar aramaya itmektedir. Yenilenebilir enerji kaynakları 7 gruba ayrılmaktadır. Bunlar, rüzgâr enerjisi, hidrolik enerji, güneş enerjisi, biyokütle enerjisi, jeotermal enerji, hidrojen enerjisi ve dalga enerjisidir (Koç, Yağl1, Koç, \& Uğurlu, 2018). Çevreye en az zarar veren enerji üretim biçimi rüzgâr enerjisidir. Herhangi bir karbon salınımı olmadığı için çevre kirliliğine ve küresel ısınmaya yol açmaz. Hammadde sıkıntısı olmadığı için sonsuz bir enerji kaynağıdır. Rüzgâr enerjisi enerji üretimi için, rüzgâr akımının yoğun, güçlü ve sürekli olduğu düz alanlara ihtiyaç duyar. Dünya üzerinde kullanılabilecek ve dönüştürülebilecek en uygun yenilenebilir enerji kaynaklarından birisidir ve bu dönüşümü yapan santrallere rüzgâr enerji santralleri (RES) adı verilmektedir (Şimşek, 2020).

Rüzgâr enerjisinin ülkemizde verimi en yüksek olan yenilenebilir enerji kaynağı olduğu ve yatırımlarının da bu bağlamda yıldan yıla artışı gözle görülmektedir. Ülkemizde rüzgâr enerjisinin durumuna bakılacak olursa, ilk rüzgâr enerjisi santrali 1.5 MegaWatt (MW) kapasite ile 1998 yılında İzmir'in Çeşme ilçesinde kurulmuştur. 1998 yılından 2005 yılına kadar rüzgâr enerjisi santrali alanında ciddi gelişmeler yaşanmamıştır. Mayıs 2005 tarihinde yürürlüğe giren 5346 numaralı Yenilenebilir Enerji Kanunu (YEK) ve gelişen teknoloji ile, rüzgâr enerjisi alanında girişimler hızlı bir ilerleme kaydetmeye başlamıştır (URL-1). Buna bağlı olarak, rüzgâr enerji santralleri için en uygun lokasyonların tespiti önem arz etmektedir. Bu analiz ve değerlendirmelerin içeriğinde, rüzgâr enerjisini ve kurulacak rüzgâr enerji santralini etkileyen, kurulum aşamasında dikkat edilmesi gereken çeşitli faktörler mevcuttur. Rüzgâr enerji santralinin kurulumu için konumun önemli bir başlık olması ve bu konuma birden fazla faktörün etki etmesi, bu faktörleri uygunluk analizleri içerisinde kullanarak, bir rüzgâr enerji santrali için en uygun hangi konumların seçilebileceği gibi coğrafi bilgi sistemleri (CBS) uygulamaları yapılmasını zorunlu kılmıştır. Faktör verilerinin elde edilmesi, uygunluk analizleri içerisinde öncelik sıralamasına sokulması ve faktörlere ağırlık verilmesi, uygulamaların sağlıklı bir sonuç vermesi açısından önemlidir.

RES kurulumu için, CBS yardımıyla en uygun yer seçimi çalışmaları başlığı altında incelenen tez ve makalelerde, (Aitzhanov, 2016; Arca \& Çıtıroğlu, 2020; Artun, 2020; Atıc1, Şimşek, Ulucan, \& Tosun, 2015; Aydin, Kentel, \& Düzgün, 2009; Baban \& Parry, 2000; Bennui, Rattanamanee, Puetpaiboon, Phukpattaranont, \& Chetpattananondh, 2007; Can \& Yücel, 2019; Latinopoulos \& Kechagia, 2015; Memduhoğlu, Özmen, Göyçek, \& Kılıç, 2014; Özşahin \& Kaymaz, 2013; Sunak, Höfer, Siddıque, Madlener, \& Doncker, 2015; Şimşek, 2020; Urfalı \& Eymen, 2021) çoğunlukla Çok Kriterli Karar Analizi (ÇKKA) yöntemlerinden Analitik Hiyerarşi Yöntemi’nin (AHY) tercih edildiği göze çarpmaktadır. Bu çalışmalarda farklı sayıda kriterler (faktörler) ele alınmış olmasına rağmen, en az sayıda kriterle yapılan çalışmalarda bile bazılarının mutlaka yer aldığı görülmüştür. Bu kriterler, rüzgâr hızı, rüzgâr kapasite faktörü, rüzgâr güç yoğunluğu verilerinden biri ya da birkaçı, enerji nakil hatları ve trafo merkezleri verilerinden biri ya da her ikisi, eğim bilgisi verisi, karayolları verisi, yerleşim alanları verisi olarak sayılabilir. Bu kriterler harici oluşan verilerin ise genel olarak bütünden özele inerek elde edildiği söylenebilir. Örneğin; arazi kullanım verisini direkt olarak kendi içinde sınıfa ayırmak yerine içindeki verileri bölerek, ormanlar, yerleşim birimleri, endüstriyel alanlar, korunan alanlar vb. gibi ayrı ayrı haritalara dönüştürüp, kriter sayısını arttırarak analize sokmak mümkündür. Ayrıca yapılan çalışmalarda kriterlerin gerek birbirlerine göre önem sıralarının gerekse kendi içlerinde yapılan uygunluk sınıflarına bölme işlemlerinin, uzman görüşlerine, incelenen çalışmalara veya ülkelerin yönetmeliklerine göre hemen her çalışma için farklılık gösterdiği gözlemlenmiştir.

Çalışma kapsamında ÇKKA yöntemlerinden biri olan AHY ile, çalışma alanı içerisinde rüzgâr enerji santrali kurulumuna etki eden faktörlerin ağırlıkları belirlenerek, Kocaeli ili için kurulabilecek, en uygun RES alanlarının tespiti yapılacaktır. 
Verilen bu bilgiler ışığında çalışmanın temel amaçları; RES'lerin yer seçimine etki eden faktörlerin belirlenmesi, etki eden faktörlerin önceliklerinin belirlenmesi ve AHY ile ağırlıklarının hesaplanması, Kocaeli ili için en uygun RES yerlerinin tespit edilmesi, etki eden faktörlere ayrıca eşit ağırlıklar verilerek uygun yerlerin bulunması ve ağırlıkları AHY ile bulunan en uygun yerler ile karşılaştırılması, Kocaeli ili içerisinde daha önceden yapılan RES'lerin konumlarının, çalışma kapsamında bulunan en uygun yerler ile örtüşüp örtüşmediğinin tespit edilmesiyle doğrulama yapılması ve bulunan sonuçların yorumlanması olarak ifade edilebilir.

\section{Metodoloji}

Uygulamada kullanılacak kriterler benzer çalışmalar incelenerek belirlenmiştir. Belirlenen kriterler için raster ve vektör formatında veriler elde edilip, uygulamada kullanılacak olan CBS yazılımına aktarılarak (ArcGIS 10.8), gerekli görülenler için kesme ve koordinat sistemi dönüşümü işlemleri yapılmıştır. Ağırlıklı çakıştırma işlemi yapabilmek için raster verilere ihtiyaç olduğundan, vektör formatında veriler mesafe (uzaklık) analizleri yapılarak raster verilere dönüştürülmüştür. Bütün veriler raster formatına dönüştürüldükten sonra, yapılan benzer çalışmalardan yola çıkılarak uygunluk sınıflarına bölünmüsşür. Ayrıca raster veri tipinde olan bütün haritalar eşit hücre boyutuna (100 x 100) getirilmiştir. Sonra kriterler 1 (1, 2, 3, 4, 5 puanlılar dahil olmak üzere tüm uygun olan alanlar), 0 (uygun olmayan alanlar) olmak üzere iki sinıfa bölünmüş, veriler üst üste çakıştırılmış ve RES için uygun olan ve olmayan alanlar (maskeleme haritası) haritası elde edilmiştir. Daha sonra bilirkişi görüşleri yardımıyla kriterler önem derecelerine göre sıralanmış ve AHY ile ağırlıkları belirlenmiştir. Bütün veriler yeniden sınıflandırma işlemine tabi tutulmuş ve belirlenen ağırlıklarıyla, uygun olan alanları kendi içinde sınıflandırabilmek için üst üste çakıştırılmıştır. Bu işlem, farklı bir bakış ve karşılaştırma olması açısından, kriterler eşit ağırlıkta kabul edilerek bir kere daha yapılmıştır. Son olarak, elde edilen ağırlıklı çakıştırma haritaları, maskeleme haritası ile örtüştürülerek, sonuç uygunluk haritaları ve sınıfları elde edilmiştir. Sonuç uygunluk haritaları, ilk olarak AHY ile belirlenen ağırlıklara göre, ikinci olarak ise kriterler eşit ağırlıkta kabul edilerek iki farklı şekilde sunulmuş ve sonuçlar yorumlanmıştır. Çalışmaya ait iş akışı Şekil 1'de sunulmuştur. 


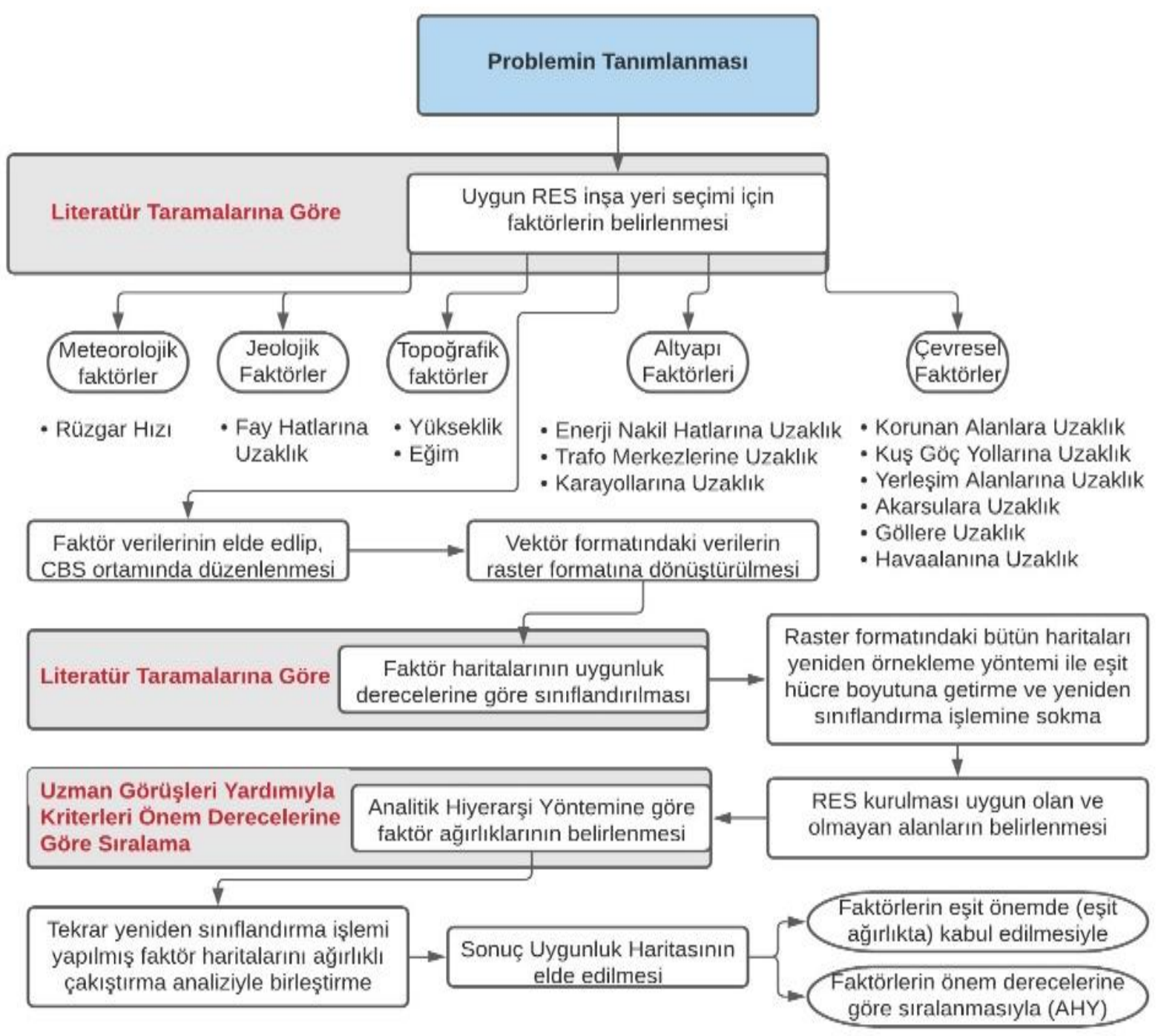

Şekil 1: Iş akış diyagramı

\section{3. Çalışma Alanı ve Veriler}

Ülkemizde T.C Enerji ve Tabii Kaynaklar Bakanlığı'na bağlı Enerji İşleri Genel Müdürlügü̆’nün rüzgâr enerjisi ile ilgili yaptığı çalışmalar mevcuttur. Bu çalışmalar ışığında, orta-ölçekli sayısal hava tahmin modeli ve mikro-ölçekli rüzgâr akış modeli kullanılarak üretilen, rüzgâr kaynak bilgilerinin verildiği Rüzgâr Enerjisi Potansiyel Atlası (REPA) hazırlanmıştır. REPA bilgilerine göre, Aralık 2020 sonu itibariyle, Türkiye rüzgâr enerjisine dayalı elektrik kurulu gücü $8.832 \mathrm{MW}$, toplam elektrik üretimi içerisindeki payı \%8.09 olmuştur (URL-2). Çalı̧̧ma kapsamında, Kocaeli ili içerisinde daha önce yapılmış veya mevcut durumda kurulumu devam eden RES'lerin varlığı (Şekil 2), Kocaeli ilinin ülke ekonomisi bakımından yoğun bir sermaye pazarı haline dönüşmesi ve bu nedenle yapılabilecek RES'ler için de yüksek yatırıma uygun oluşu ve ilin bir geçiş bölgesi olması gibi nedenler, Kocaeli ilinin seçimi için başlıca etkenlerdir.

RES yapımı için rüzgâr hızı çok önemli bir faktördür. Bu çalışmada REPA'nın sağladığı Kocaeli ili için 100 metrede yıllık ortalama rüzgâr hızı dağııımı haritası kullanılmıştır. Ayrıca, Türkiye 100 metrede yıllık ortalama rüzgâr hızı dağılımı haritası da Şekil 3 üzerinden incelenebilir.

Çalışma içerisinde uygulamaların verilerle entegre olarak en uygun doğrulukta sonuçlar çıkarabilmesi amacıyla, tüm haritalar 
TUREF TM30 projeksiyonunda tanımlanmıştır.

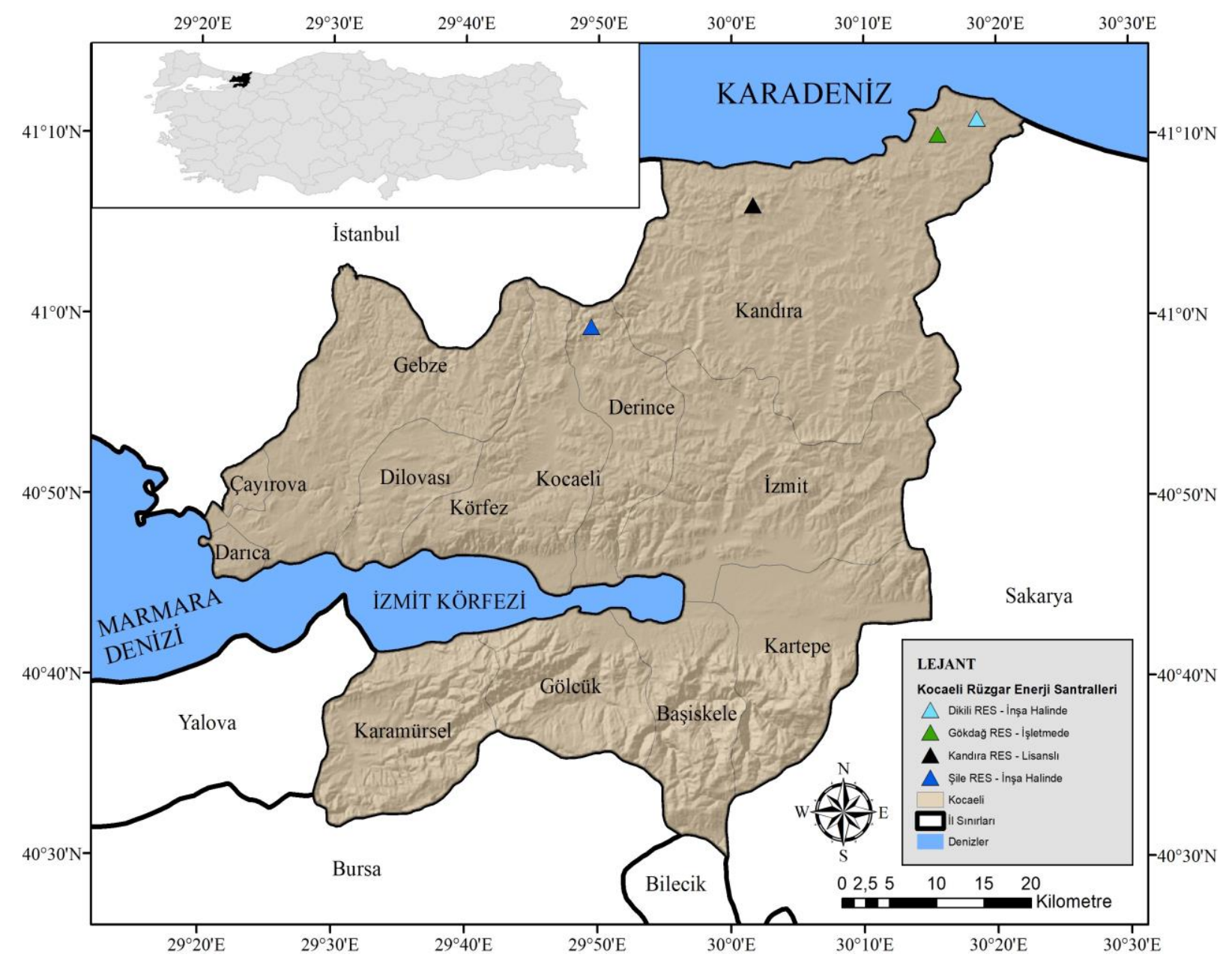

Şekil 2: Kocaeli il haritası ve içerisindeki RES konumları (RES Konumları Kaynağı: (TÜREB, 2020))
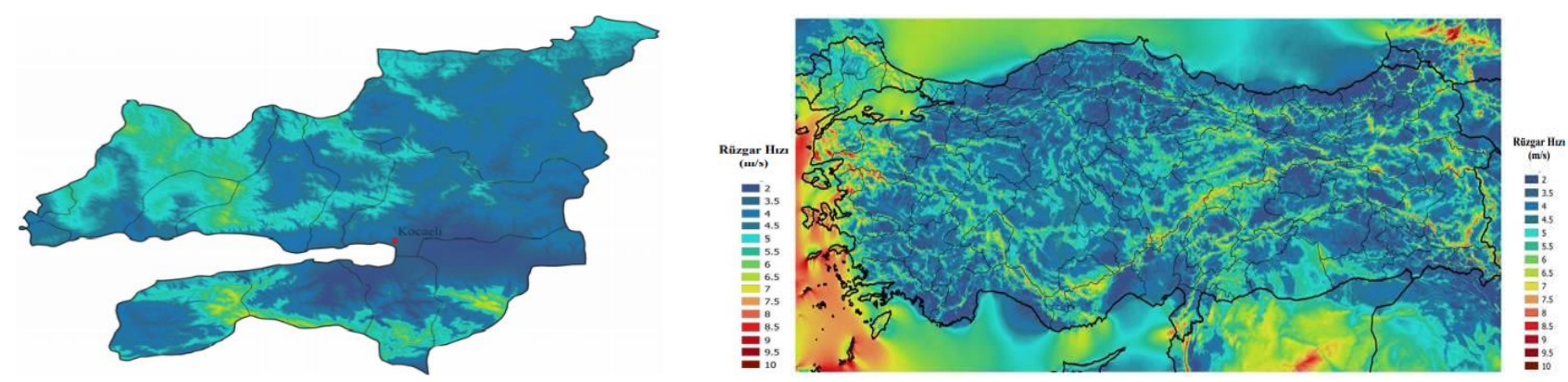

Şekil 3: (sol) REPA Kocaeli ili 100 metre yükseklikte yıllık ortalama rüzgâr hızı dağılım haritası, (sağ) REPA Türkiye geneli 100 metre yükseklikte yıllık ortalama rüzgâr hızı dağılım haritası (URL-3)

Çalışmada kullanılan faktörler aşağıdaki tablo üzerinde gösterilmiştir. Bazı veriler kaynağından direkt elde edildiği şekilde, bazıları ise sayısallaştırma işlemi yapılarak kullanılmıştır. Çalışmada kullanılan faktörlerin verileri CBS yazılım programı üzerinde düzenlendikten sonra ilk olarak, geçmişte yapılan çalışmalar incelenerek, RES için uygun olmayan alan olarak kabul edilen veri sınıfları belirlenmiştir (Tablo 1). 
Tablo 1: Dikkate alınan faktörler ve RES için uygun olmayan sınıfları

\begin{tabular}{|c|c|c|c|c|c|c|}
\hline Faktör & $\begin{array}{l}\text { Verinin } \\
\text { Yapısı }\end{array}$ & $\begin{array}{l}\text { Verinin } \\
\text { Kullanım Şekli }\end{array}$ & $\begin{array}{l}\text { Verinin } \\
\text { Türü }\end{array}$ & Verinin Kaynağı & $\begin{array}{l}\text { Faktörün Uygun } \\
\text { Olmayan Sinıfları }\end{array}$ & $\begin{array}{l}\text { Sınıflandırma } \\
\text { Kaynağı }\end{array}$ \\
\hline Rüzgâr Hızı & Raster & Sayısallaştırma & $\begin{array}{l}\text { Nokta } \\
\text { (Point) }\end{array}$ & REPA (URL-3) & $<5 \mathrm{~m} / \mathrm{s}$ & $\begin{array}{l}\text { (Baban \& Parry, 2000; } \\
\text { Özşahin \& Kaymaz, } \\
\text { 2013) }\end{array}$ \\
\hline $\begin{array}{l}\text { Korunan } \\
\text { Alanlar }\end{array}$ & Vektör & Direkt & $\begin{array}{l}\text { Alan } \\
\text { (Polygon) }\end{array}$ & $\begin{array}{l}\text { (C) OpenStreetMap } \\
\text { Katılımcıları (URL-4) }\end{array}$ & $<2000 \mathrm{~m}$ & $\begin{array}{l}\text { (Atıcı vd., 2015; } \\
\text { Bennui vd., 2007) }\end{array}$ \\
\hline $\begin{array}{l}\text { Kuş Göç } \\
\text { Yolları }\end{array}$ & Raster & Sayısallaştırma & $\begin{array}{l}\text { Çizgi } \\
\text { (Line) }\end{array}$ & $\begin{array}{l}\text { birdmap.5dvision.ee } \\
\text { (URL-5) }\end{array}$ & $<500 \mathrm{~m}$ & $\begin{array}{l}\text { (Aitzhanov, 2016; } \\
\text { Aydin vd., 2009) }\end{array}$ \\
\hline $\begin{array}{l}\text { Trafo } \\
\text { Merkezleri }\end{array}$ & Vektör & Direkt & Nokta & $\begin{array}{l}\text { Sakarya Elektrik } \\
\text { Dağıtım A.Ş. (SEDAŞ) } \\
\text { Kocaeli Bölgesi }\end{array}$ & $>25000 \mathrm{~m}$ & $\begin{array}{l}\text { (Özşahin \& Kaymaz, } \\
\text { 2013; Urfalı \& Eymen, } \\
\text { 2021) }\end{array}$ \\
\hline $\begin{array}{l}\text { Enerji Nakil } \\
\text { Hatları }\end{array}$ & Vektör & Direkt & Çizgi & $\begin{array}{l}\text { SEDAŞ Kocaeli } \\
\text { Bölgesi }\end{array}$ & $\begin{array}{l}<100 \mathrm{~m} \mathrm{ve} \\
>10000 \mathrm{~m}\end{array}$ & $\begin{array}{l}\text { (Sunak vd., 2015) / } \\
\text { (Baban \& Parry, 2000) }\end{array}$ \\
\hline $\begin{array}{l}\text { Yerleşim } \\
\text { Alanları }\end{array}$ & Vektör & Direkt & Alan & $\begin{array}{l}\text { (C) OpenStreetMap } \\
\text { Katılımciları (URL-4) }\end{array}$ & $<2000 \mathrm{~m}$ & $\begin{array}{l}\text { (Atıc1 vd., 2015; Aydin } \\
\text { vd., 2009; Baban \& } \\
\text { Parry, 2000) }\end{array}$ \\
\hline Karayolları & Vektör & Direkt & Cizgi & (C) OpenStreetMap & $<100 \mathrm{~m} \mathrm{ve}$ & $\begin{array}{l}\text { (Baban \& Parry, 2000; } \\
\text { Urfalı \& Eymen, 2021) }\end{array}$ \\
\hline Narayonart & V EKIOI & Dाreкt & ÇIZgI & Katılımcıları (URL-4) & $>10000 \mathrm{~m}$ & $\begin{array}{l}\text { (Baban \& Parry, 2000) } \\
\text { (Can \& Yücel, 2019; }\end{array}$ \\
\hline Fay Hatları & Raster & Sayısallaştırma & Çizgi & MTA (URL-6) & $<1000 \mathrm{~m}$ & $\begin{array}{l}\text { Arca \& Çitıroğlu, } \\
\text { 2020; Artun, 2020) }\end{array}$ \\
\hline $\begin{array}{l}\text { Sayısal } \\
\text { Yükseklik } \\
\text { Modeli }\end{array}$ & Raster & Direkt & Piksel & $\begin{array}{l}\text { USGS Earth Explorer } \\
\text { (URL-7) }\end{array}$ & $>1500 \mathrm{~m}$ & $\begin{array}{l}\text { (Atıcı vd., 2015; Can \& } \\
\text { Yücel, 2019) }\end{array}$ \\
\hline Eğim & Raster & $\begin{array}{l}\text { Sayısal } \\
\text { Yükseklik } \\
\text { Modelinden } \\
\text { Üretilerek }\end{array}$ & Piksel & $\begin{array}{l}\text { Sayısal Yükseklik } \\
\text { Modeli }\end{array}$ & $>\% 30$ & $\begin{array}{l}\text { (Aitzhanov, 2016; } \\
\text { Özşahin \& Kaymaz, } \\
\text { 2013; Sunak vd., 2015; } \\
\text { Şimşek, 2020) }\end{array}$ \\
\hline Akarsular & Vektör & Vektör & Çizgi & $\begin{array}{l}\text { (C) OpenStreetMap } \\
\text { Katılımcıları (URL-4) }\end{array}$ & $<3000 \mathrm{~m}$ & $\begin{array}{l}\text { (Aitzhanov, 2016; Atıc1 } \\
\text { vd., 2015) }\end{array}$ \\
\hline Göller & Vektör & Vektör & Alan & $\begin{array}{l}\text { (C) OpenStreetMap } \\
\text { Katılımcıları (URL-4) }\end{array}$ & $<3000 \mathrm{~m}$ & $\begin{array}{l}\text { (Aitzhanov, 2016; Atıc1 } \\
\text { vd., 2015) }\end{array}$ \\
\hline Havaalanı & Vektör & Vektör & Alan & $\begin{array}{l}\text { (C) OpenStreetMap } \\
\text { Katılımcıları (URL-4) }\end{array}$ & $<3000 \mathrm{~m}$ & $\begin{array}{l}\text { (Bennui vd., 2007; } \\
\text { Latinopoulos \& } \\
\text { Kechagia, 2015; Urfalı } \\
\text { \& Eymen, 2021) }\end{array}$ \\
\hline
\end{tabular}

\section{Yöntem}

Günümüzde RES yapımı için bilgi teknolojilerine dayalı sistemler kullanılabilir. CBS uygulamaları içinde en çok kullanılanı, ÇKKA yöntemlerinden biri olan AHY'dir. Analitik Hiyerarşi Süreci (Analytic Hierarchy Process, AHP) olarakta tanımlanan AHY 1970'li yıllarda Thomas L. Saaty tarafından ortaya çıkarılmıştır. Bu konudaki ilk yazılı eser, Saaty'nin 1980 yılında yayımlanan "The Analytic Hierarcy Process" adlı eseridir. Bu eser sonrasında AHY kullanılarak pek çok uygulamalı ve teorik çalışmalar yapılmıştır (Demirci, 2019; Tütek, Gümüş̧oğlu, \& Özdemir, 2012). AHY sayesinde fiziksel ve sosyal olguların birlikte ölçülmesi mümkün hale gelmiştir (Saaty \& Vargas, 2001). AHY, akılcı yönü, hızlı bir şekilde problemi çözmeye odaklanması, problemin yapısında bulunan faktörler arasında öncelikli ve baskın olanı bilmeye ve deneyimlemeye imkân vermesi, problemi, içerdiği etki ve ilişkilerle birlikte bütünleşik bir modelde geliştirme imkânı sunması gibi avantajları bakımından çokça tercih edilen bir yöntemdir (Güler, 2016; Saaty, 1994). İlgili bu yöntem sayesinde RES yapımında etkili olan faktörler önem derecelerine göre sıralanarak, farklı formüller yardımıyla ağırlıkları bulunur. Bunun ardından çalışma alanı içerisinde, CBS yardımıyla en uygun konumlar belirlenerek, yüklenici firmanın kullanacağı rüzgâr türbini modeline göre, konum seçimi yapılabilir duruma gelmiş olur.

Saaty AHY’nin temelini yansıtan 4 aksiyom tanımlamıştır (Saaty, 1986; Saat, 2000):

- Aksiyom 1 - Terslik Koşulu: Karar veren kişi, karşılaştırmalar yapmalı ve tercihlerin gücünü belirleyebilmelidir. 
Bu tercihlerin gücü belirlenirken terslik koşulu sağlanmalıdır. Eğer A kriteri B kriterine göre 5 kat daha öncelikliyse, B kriteri A'ya göre 1/5 kat öncelikli kabul edilmelidir. Bu koşulun uygulanmaması, problemin ya da öncelik kıyaslamalarının yeterince açık olmadığını veya doğru belirtilmediğini gösterir.

- Aksiyom 2 - Homojenlik: Benzer ögelerin karşılaştırılması gerektiğini ifade eder. Örneğin bir elma ile bir karpuz büyüklük açısından karşılaştırıldığında fark büyük olacaktır. Bu durumda karşılaştırılan ögelerin kümelendirilmesi gerekir.

- Aksiyom 3 - Bağımsızlık: Tercihler yapıldığı zaman, kriterler alternatiflerin özelliklerinden bağımsız olarak kabul edilir.

- Aksiyom 4 - Beklentiler: Beklentileri temsil edecek sonuç için tüm kriterlerin hiyerarşide yer aldığından emin olunmalıdır. Bu koşulun ihlal edilmesi halinde karar veren kişi, tüm kriterleri kullanmamış ve yetersiz bir sonuca ulaşmış olur.

Karar problemi için, problemin hedefini, kriterlerini ve alternatiflerini belirten hiyerarşik bir yapı kurulmalıdır. İlk aşamada hedef belirlenir ve herhangi bir karşılaştırma yapılmaz. İkinci aşamada bütün kriterler, hedef göz önünde bulundurularak, birbirlerine karşı önem derecelerine göre ikili karşılaştırmaya tabi tutulur. Üçüncü aşamada ise bütün alternatifler için, her bir kriter üzerinden ikili karşılaştırmalar yapılarak önem yüzde dağılımları elde edilir (Pala, 2013).

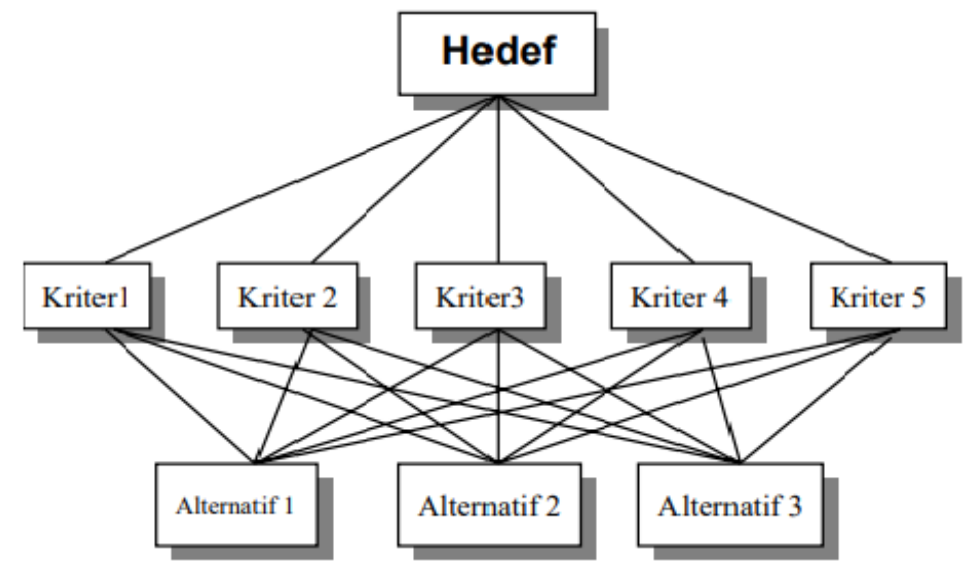

Şekil 4: AHY hiyerarşik yapısı (Pala, 2013)

AHY'de ölçeğin belirlenmesi çok önemlidir. Standart ölçekler para birimi, uzunluk birimi veya 1sı derecesi gibi birimlerle oluşur. Bu ölçekler belli bir özelliği ölçmek için geliştirilen birimlerle nesneler ya da olayların ölçülmesine yarar. Ölçekteki sayılar insan zihninde uyarıcı bir işlev görmesine rağmen kendi başlarına bir değerleri yoktur. Bu tür ölçekleri kullanmayan, göreli ölçüm yöntemi adını taşıyan daha genel bir ölçüm yöntemi de vardır. Göreli ölçüm yöntemi, soyut, maddi olmayan özellikleri (sevgi, doğruluk vb.) ölçmek için de kullanılabilir. Diğer bir önemli özelliği ise gerekli hallerde standart ölçekten elde edilebilen bilgileri de kullanabilmesidir. Böyle bir durumda standart oran ölçeğinden elde edilen ölçümler normal hale getirilerek göreli ölçekteki ölçümlere dönüştürülebilir. Eğer ele alınan özellikle ilgili önceliğin ya da önem derecesinin ifade edilmesi gerekirse göreli bir ölçeğe ihtiyaç vardır. Göreli ölçek bu durumda, standart ölçekle ifade edilen verilerin gerçekte neyi yansıttığını anlamak için büyük bir yardımcıdır ve birçok durumda ihtiyaç duyulmaktadır (Saaty, 1990; Saat, 2000).

Saaty (1994) tarafından AHY için kullanılmak üzere göreli bir puanlandırma ölçeği geliştirilmiştir (Tablo 2). 
Tablo 2: Analitik hiyerarşi yöntemi puanlandırma ölçeği (Saaty, 1994)

\begin{tabular}{|c|c|c|c|c|c|c|c|c|c|}
\hline $\begin{array}{l}\text { Temel Ölçek } \\
\text { (Satır ve Sütun) }\end{array}$ & $\begin{array}{l}\text { Eşit } \\
\text { Önem }\end{array}$ & Ara Değer & $\begin{array}{l}\text { Orta } \\
\text { Derecede } \\
\text { Daha } \\
\text { Önemli } \\
\end{array}$ & Ara Değer & $\begin{array}{l}\text { Güçlü } \\
\text { Derecede } \\
\text { Daha } \\
\text { Önemli }\end{array}$ & Ara Değer & $\begin{array}{l}\text { Çok Güçlü } \\
\text { Derecede } \\
\text { Daha } \\
\text { Önemli }\end{array}$ & Ara Değer & $\begin{array}{l}\text { Son Derece } \\
\text { Daha } \\
\text { Önemli }\end{array}$ \\
\hline Değerler & 1 & 2 & 3 & 4 & 5 & 6 & 7 & 8 & 9 \\
\hline
\end{tabular}

AHY adımları (Pala, 2013; Yaralığlu, 2004) aşağıdaki şekilde verilebilir:

Adım 1: Karar verme probleminin tanımlanmasıdır. Karar verme probleminin tanımlanması iki aşamadan oluşur. Birinci aşama, karar probleminde, aralarından seçim yapılması gereken alternatiflerin belirlenmesi işlemidir. Alternatifler bu çalışma için, piksellere ayrılmış bütün Kocaeli ilidir. İkinci aşama ise seçimi yaparken etkisi bulunan kriterlerin belirlenmesidir. Kriterlerin açık ve detaylı tanımlamalarının yapılması, problemin en doğru ve güvenilir çözüme ulaşması açısından çok önemlidir. Alternatiflerin sayısı m, kriterlerinki ise n olarak kabul edilmiştir. Kriter sayısı (n) bu çalışma için 13 'tür.

Adım 2: Kriterler arası karşılaştırma matrisinin elde edilmesidir. Kriterler arası karşılaştırma matrisi, n x n boyutlu, aynı sırada satır ve sütunlara yazılan kriterlerin birbirleriyle ikili karşılaştırılmalarından oluşan bir kare matristir. Kare matrisin köşegen noktaları, aynı kriterler aynı önem derecesine sahip olduğundan dolayı 1 değerini alır. A karşılaştırma matrisinin elemanları kriterler arası ikili karşılaştırmaların sonuçlarını vermektedir. Kriterlerin ikili karşılaştırılmalarında AHY puanlandırma ölçeği (Tablo 2) kullanılır. Örnek olarak birinci kriter, ikinci kritere göre güçlü derecede daha önemli ise, A matrisinin $\mathrm{a}_{12}$ bileşeni 5 değerini alacaktır. Tam tersi durumda yani ikinci kriter, birinci kritere göre güçlü derecede daha önemli olursa, bu kez aynı matris elemanı olan $\mathrm{a}_{12}$, 1/5 değerini alacaktır (Tablo 3). 
Tablo 3: A karşılaştırma matrisi

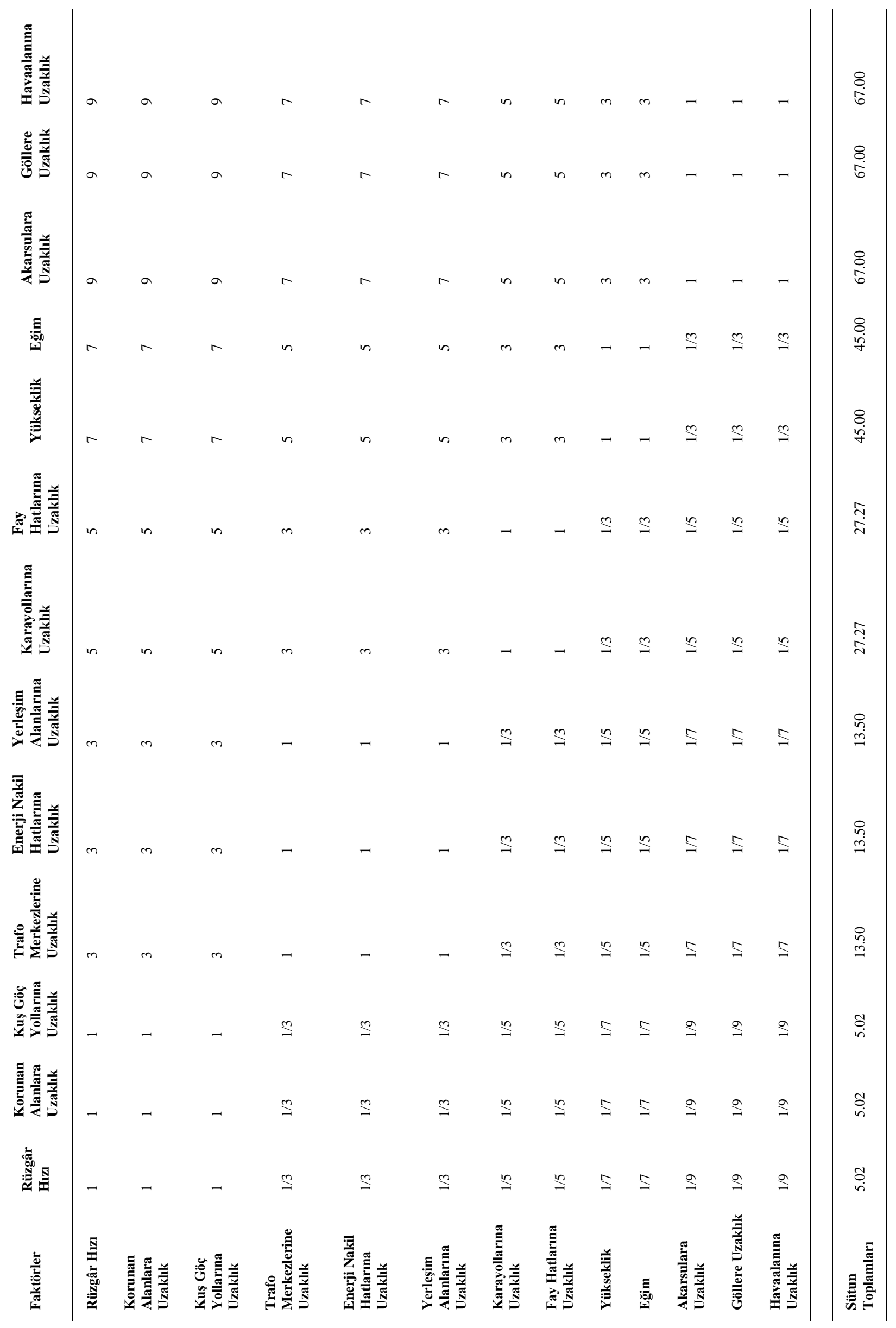


Adım 3: Kriterlerin yüzde önem dağılımlarının elde edilmesidir. Kriterlerin normalize edilmiş ikili karşılaştırmalar matrisinin elemanları, A karşılaştırma matrisindeki her elemanın, ait olduğu sütunun toplamına bölünmesiyle elde edilir (Tablo 4).

Tablo 4: Normalizasyon matrisi

\begin{tabular}{lllllllllllllll}
\hline 1 & 0.1992 & 0.1992 & 0.1992 & 0.2223 & 0.2223 & 0.2223 & 0.1834 & 0.1834 & 0.1556 & 0.1556 & 0.1343 & 0.1343 & 0.1343 \\
2 & 0.1992 & 0.1992 & 0.1992 & 0.2223 & 0.2223 & 0.2223 & 0.1834 & 0.1834 & 0.1556 & 0.1556 & 0.1343 & 0.1343 & 0.1343 \\
3 & 0.1992 & 0.1992 & 0.1992 & 0.2223 & 0.2223 & 0.2223 & 0.1834 & 0.1834 & 0.1556 & 0.1556 & 0.1343 & 0.1343 & 0.1343 \\
4 & 0.0664 & 0.0664 & 0.0664 & 0.0741 & 0.0741 & 0.0741 & 0.1100 & 0.1100 & 0.1111 & 0.1111 & 0.1045 & 0.1045 & 0.1045 \\
5 & 0.0664 & 0.0664 & 0.0664 & 0.0741 & 0.0741 & 0.0741 & 0.1100 & 0.1100 & 0.1111 & 0.1111 & 0.1045 & 0.1045 & 0.1045 \\
6 & 0.0664 & 0.0664 & 0.0664 & 0.0741 & 0.0741 & 0.0741 & 0.1100 & 0.1100 & 0.1111 & 0.1111 & 0.1045 & 0.1045 & 0.1045 \\
7 & 0.0398 & 0.0398 & 0.0398 & 0.0247 & 0.0247 & 0.0247 & 0.0367 & 0.0367 & 0.0667 & 0.0667 & 0.0746 & 0.0746 & 0.0746 \\
8 & 0.0398 & 0.0398 & 0.0398 & 0.0247 & 0.0247 & 0.0247 & 0.0367 & 0.0367 & 0.0667 & 0.0667 & 0.0746 & 0.0746 & 0.0746 \\
9 & 0.0285 & 0.0285 & 0.0285 & 0.0148 & 0.0148 & 0.0148 & 0.0122 & 0.0122 & 0.0222 & 0.0222 & 0.0448 & 0.0448 & 0.0448 \\
10 & 0.0285 & 0.0285 & 0.0285 & 0.0148 & 0.0148 & 0.0148 & 0.0122 & 0.0122 & 0.0222 & 0.0222 & 0.0448 & 0.0448 & 0.0448 \\
11 & 0.0221 & 0.0221 & 0.0221 & 0.0106 & 0.0106 & 0.0106 & 0.0073 & 0.0073 & 0.0074 & 0.0074 & 0.0149 & 0.0149 & 0.0149 \\
12 & 0.0221 & 0.0221 & 0.0221 & 0.0106 & 0.0106 & 0.0106 & 0.0073 & 0.0073 & 0.0074 & 0.0074 & 0.0149 & 0.0149 & 0.0149 \\
13 & 0.0221 & 0.0221 & 0.0221 & 0.0106 & 0.0106 & 0.0106 & 0.0073 & 0.0073 & 0.0074 & 0.0074 & 0.0149 & 0.0149 & 0.0149 \\
\hline
\end{tabular}

Öncelik vektörü $(\mathbf{W})$, normalizasyon matrisinin her bir satır toplamının, kullanılan faktör sayısına (13) bölünmesiyle elde edilir (Tablo 5). Yapılacak tutarlılık kontrolü sonrasında istenilen tutarlılığa ulaşıldığı zaman, faktörlerin ağırlıkları bu değerler olmuş olur.

Tablo 5: W öncelik vektörü

\begin{tabular}{lllllllllllll}
\hline 1 & 2 & 3 & 4 & 5 & 6 & 7 & 8 & 9 & 10 & 11 \\
\hline 0.180 & 0.180 & 0.180 & 0.091 & 0.091 & 0.091 & 0.048 & 0.048 & 0.026 & 0.026 & 0.013 & 0.013 & 0.013 \\
\hline
\end{tabular}

Adım 4: Kriterlerin karşılaştırılmasındaki tutarlılık ölçülür. Yöntem tutarlılık kontrolü için bir süreç içermektedir. Tutarlılık Oranı (Consistency Ratio, CR), kriterler arasında yapılan ikili karşılaştırmaların ne derece tutarlı olduğunu görebilmek için hesaplanır. CR'nin hesaplanabilmesi için ilk önce Temel Değer ( $\lambda$ ) katsayısını belirlemek gerekmektedir. $\lambda$ katsayısını elde edebilmek için ise A karşılaştırma matrisi ile W öncelik vektörünü, matris çarpımı işlemine sokarak, aşağıda gösterilen $\mathbf{D}$ sütun vektörü bulunmalıdır (Tablo 6).

Tablo 6: $D$ sütun vektörü

\begin{tabular}{|c|c|c|c|c|c|c|c|c|c|c|c|c|}
\hline 1 & 2 & 3 & 4 & 5 & 6 & 7 & 8 & 9 & 10 & 11 & 12 & 13 \\
\hline 2.553 & 2.553 & 2.553 & 1.275 & 1.275 & 1.275 & 0.648 & 0.648 & 0.334 & 0.334 & 0.175 & 0.175 & 0.175 \\
\hline
\end{tabular}

D sütun vektörünün her elemanı, W öncelik vektöründe karşılık gelen elemana bölünür. Bulunan bu değerler toplanarak aritmetik ortalaması alınır. Bir başka ifadeyle, bulunan değerlerin toplamı faktör sayısına (13) bölünür. Sonuçta çıkan değer, $\lambda$ katsayısı olmuş olur ( $\lambda$ katsayısı: 13.64193705). $\lambda$ katsayısı hesaplandıktan sonra Tutarlılık Göstergesi (Consistency Index, CI) aşağıdaki gibi bulunur:

$\mathrm{CI}=(\lambda-$ faktör sayısı $(13)) /($ faktör sayısı $(13)-1)=0.053494755$

CR değeri, CI değerinin Random Gösterge (Random Index, RI) olarak ifade edilen standart düzeltme değerine bölünmesiyle 0.034291509 olarak elde edilir. Çalışmada kullanılan faktör sayısı 13 olduğundan, RI değeri olarak (Tablo 7), 1.56 sayısı 
kullanılmıştır.

Tablo 7: RI değerleri (Harker, 1989)

\begin{tabular}{|c|c|c|c|c|c|c|c|c|c|c|c|c|c|c|c|}
\hline $\mathrm{n}$ & 1 & 2 & 3 & 4 & 5 & 6 & 7 & 8 & 9 & 10 & 11 & 12 & 13 & 14 & 15 \\
\hline RI & 0.00 & 0.00 & 0.58 & 0.90 & 1.12 & 1.24 & 1.32 & 1.41 & 1.45 & 1.49 & 1.51 & 1.48 & 1.56 & 1.57 & 1.59 \\
\hline
\end{tabular}

Eğer bulunan CR değeri 0.10’dan küçük ise karar veren kişinin yaptığı ikili karşılaştırmaların tutarlı olduğu kabul edilir. Eğer CR değeri 0.10'dan büyük ise karar veren kişinin yaptığı ikili karşılaştırmalar tutarsızdır ve bunları tekrar gözden geçirmelidir. Bulunan CR değeri 0.10'dan küçük olduğundan yapılan ikili karşılaştırmalar tutarlıdır. Yani W öncelik vektöründe çıkan değerler, belirlenen faktörlerin ağırlıkları olarak kullanılabilir. Faktörlerin ağırlıkları, ayrıca yüzdesel olarak Tablo 8'de belirtilmektedir.

Adım 5: Her bir kriter için, m adet alternatifin yüzde önem dağılımlarının elde edilmesi işlemidir. AHY bu adımda her bir kriter için ayrı tablo oluşturmak suretiyle alternatifleri ikili karşıllaştırmalara tabi tutar. Bu aşamadaki işlemler 2 . ve 3. adımlarda anlatılan şekilde ilerler. Alternatiflerin sayısını $\mathrm{m}$ olarak kabul ettiğimiz için $\mathrm{n}$ adet $\mathrm{m}$ x $\mathrm{m}$ boyutunda G karşılaştırma matrisi oluşturulur. Alternatifler arası ikili karşılaştırmalar yapılırken yine AHY puanlandırma ölçeği kullanılır. Her $\mathbf{G}$ karşılaştırma matrisi için, alternatiflerin kriterlere göre yüzde önem değerlerini gösteren $\mathrm{m}$ x 1 boyutlu $\mathbf{S}$ sütun vektörleri (öncelik vektörleri) elde edilir.

Adım 6: Alternatiflerin sonuç dağılımının bulunmasıdır. Son aşama olan alternatiflerin sonuç dağılımlarının yani ağırlıklarının bulunması için ilk önce $n$ adet $\mathbf{S}$ sütun vektöründen oluşan $\mathrm{m}$ x $\mathrm{n}$ boyutlu karar matrisi $(\mathbf{K})$ elde edilir. $\mathbf{K}$ matrisinin, kriterlerin ağırlığını belirten $\mathbf{W}$ öncelik vektörü ile çarpımı sonucu $\mathbf{L}$ sütun vektörü elde edilir. $\mathbf{L}$ sütun vektörü m x 1 boyutlu olup, $\mathrm{m}$ adet alternatifin hedef açısından yüzde dağılımını verir. Bu dağılım karar probleminde alternatiflerin önem sıralamalarını yani sonuç ağırlıklarını gösterir.

Çalışmada, AHY'nin ilk 4 adımı uygulanmıştır. Problemi çözmek için kullanılan faktörlerin (kriterlerin), önem derecelerine göre karşılaştırılmaları yapılarak, problemin çözümüne giden yoldaki ağırlıkları belirlenmiştir. AHY'de belirtilen alternatifler bu çalışma için bütün Kocaeli ilidir. Ağırlıklı çakıştırma için bütün faktör haritaları sınıflandırılmalarıyla beraber raster formatına çevrildiğinden dolayı, raster hücrelerine bölünen Kocaeli ili, problemin alternatiflerini oluşturmaktadır. Yani her bir raster hücresi bir alternatifi belirtmektedir. AHY'nin 5. ve 6. adımını, faktör ağırlıkları belirlenip, ağırlıklı çakıştırma işlemi başlatıldıktan sonra CBS yazılım programı yapmaktadır. Uygunluk derecesine göre alternatifleri, yani hücrelere ayrılmış Kocaeli ilini, her hücre için sonuç uygunluğunu belirtir şekilde sunmaktadır.

\section{Bulgular}

RES kurulamayacak alanlar (Tablo 1) belirlendikten sonra, kullanılan faktörleri uygunluk sınıflarına bölme işlemine geçilmiştir. Faktörlerin, Aitzhanov (2016), Aydin vd. (2009), Bennui vd. (2007), Şimşek (2020), Urfalı ve Eymen (2021) çalışmalarından yola çıkılarak 6 sınıfa bölünmesi planlanmıştır. 0 puan (Uygun Değil) - 5 puan (Son Derece Uygun) aralığında sınıflandırılmaları yapılmıştır. Bu aşamada da yine çoğu faktörde, geçmişte yapılan çalışmalara benzer aralıklarda bölümlendirmeler yapılmasına dikkat edilmiştir. 
Tablo 8: Faktörlerin uygunluk sınıfları, öncelik sıraları ve sonuç ağırlık yüzdeleri

\begin{tabular}{|c|c|c|c|c|c|c|c|c|c|}
\hline \multirow[b]{2}{*}{ Faktörler } & \multicolumn{6}{|c|}{ Uygunluk Sınıfları ve Değerleri } & \multirow[b]{2}{*}{ Kaynak } & \multirow[b]{2}{*}{$\begin{array}{c}\text { AHY Öncelik } \\
\text { Sırası }\end{array}$} & \multirow[b]{2}{*}{$\begin{array}{c}\text { AHY Ağırlık } \\
(\%)\end{array}$} \\
\hline & $\begin{array}{l}\text { Son } \\
\text { Derece } \\
\text { Uygun } \\
(5) \\
\end{array}$ & $\begin{array}{c}\text { Çok } \\
\text { Uygun } \\
\text { (4) }\end{array}$ & $\begin{array}{l}\text { Uygun } \\
\text { (3) }\end{array}$ & $\begin{array}{l}\text { Orta } \\
\text { Derece } \\
\text { Uygun } \\
(2) \\
\end{array}$ & $\begin{array}{c}\text { Az } \\
\text { Uygun } \\
\text { (1) }\end{array}$ & $\begin{array}{l}\text { Uygun } \\
\text { Değil } \\
(\mathbf{0})\end{array}$ & & & \\
\hline $\begin{array}{l}\text { Rüzgar Hızı } \\
(\mathrm{m} / \mathrm{s})\end{array}$ & $\begin{array}{c}6.40- \\
6.70\end{array}$ & $\begin{array}{c}6.05- \\
6.40\end{array}$ & $\begin{array}{l}5.70- \\
6.05\end{array}$ & $\begin{array}{l}5.35- \\
5.70\end{array}$ & $\begin{array}{c}5- \\
5.35\end{array}$ & $\begin{array}{c}2.23- \\
5\end{array}$ & - & 1 & 18.0 \\
\hline $\begin{array}{l}\text { Korunan } \\
\text { Alanlara } \\
\text { Uzaklık (m) }\end{array}$ & $>4000$ & $\begin{array}{c}3500- \\
4000\end{array}$ & $\begin{array}{c}3000- \\
3500\end{array}$ & $\begin{array}{c}2500- \\
3000\end{array}$ & $\begin{array}{l}2000- \\
2500\end{array}$ & $0-2000$ & $\begin{array}{l}\text { (Bennui vd., } \\
\text { 2007) }\end{array}$ & 1 & 18.0 \\
\hline $\begin{array}{l}\text { Kuş Göç } \\
\text { Yollarına } \\
\text { Uzaklık (m) }\end{array}$ & $>2500$ & $\begin{array}{c}2000- \\
2500\end{array}$ & $\begin{array}{c}1500- \\
2000\end{array}$ & $\begin{array}{c}1000- \\
1500\end{array}$ & $\begin{array}{l}500- \\
1000\end{array}$ & $\begin{array}{l}0- \\
500\end{array}$ & $\begin{array}{l}\text { (Aitzhanov, } \\
\text { 2016) }\end{array}$ & 1 & 18.0 \\
\hline $\begin{array}{l}\text { Trafo } \\
\text { Merkezlerine } \\
\text { Uzaklık (m) }\end{array}$ & $<1000$ & $\begin{array}{c}1000- \\
5000\end{array}$ & $\begin{array}{l}5000- \\
10000\end{array}$ & $\begin{array}{c}10000- \\
15000\end{array}$ & $\begin{array}{c}15000- \\
25000\end{array}$ & $>25000$ & $\begin{array}{c}\text { (Özşahin \& } \\
\text { Kaymaz, 2013; } \\
\text { Urfalı \& Eymen, } \\
\text { 2021) }\end{array}$ & 2 & 9.1 \\
\hline $\begin{array}{l}\text { Enerji Nakil } \\
\text { Hatlarına } \\
\text { Uzaklık (m) }\end{array}$ & $\begin{array}{l}100- \\
500\end{array}$ & $\begin{array}{l}500- \\
1000\end{array}$ & $\begin{array}{l}1000- \\
2500\end{array}$ & $\begin{array}{c}2500- \\
5000\end{array}$ & $\begin{array}{l}5000- \\
10000\end{array}$ & $\begin{array}{l}<100 \\
\text { ve } \\
>10000\end{array}$ & $\begin{array}{c}\text { (Urfalı \& } \\
\text { Eymen, 2021) }\end{array}$ & 2 & 9.1 \\
\hline $\begin{array}{l}\text { Yerleşim } \\
\text { Alanlarına } \\
\text { Uzaklık (m) }\end{array}$ & $>4000$ & $\begin{array}{c}3500- \\
4000\end{array}$ & $\begin{array}{l}3000- \\
3500\end{array}$ & $\begin{array}{c}2500- \\
3000\end{array}$ & $\begin{array}{c}2000- \\
2500\end{array}$ & $<2000$ & $\begin{array}{c}\text { (Urfalı \& } \\
\text { Eymen, 2021) }\end{array}$ & 2 & 9.1 \\
\hline $\begin{array}{l}\text { Karayollarina } \\
\text { Uzaklık (m) }\end{array}$ & $\begin{array}{l}100- \\
1000\end{array}$ & $\begin{array}{c}1000- \\
2000\end{array}$ & $\begin{array}{c}2000- \\
3000\end{array}$ & $\begin{array}{c}3000- \\
4000\end{array}$ & $\begin{array}{l}4000- \\
10000\end{array}$ & $\begin{array}{c}<100 \\
\text { ve } \\
>10000\end{array}$ & $\begin{array}{c}\text { (Baban \& Parry, } \\
\text { 2000) }\end{array}$ & 3 & 4.8 \\
\hline $\begin{array}{l}\text { Fay Hatlarına } \\
\text { Uzaklık (m) }\end{array}$ & $>5000$ & $\begin{array}{c}4000- \\
5000\end{array}$ & $\begin{array}{c}3000- \\
4000\end{array}$ & $\begin{array}{c}2000- \\
3000\end{array}$ & $\begin{array}{c}1000- \\
2000\end{array}$ & $<1000$ & (Artun, 2020) & 3 & 4.8 \\
\hline Yükseklik (m) & $\begin{array}{l}750- \\
1500\end{array}$ & $\begin{array}{l}450- \\
750\end{array}$ & $\begin{array}{l}300- \\
450\end{array}$ & $\begin{array}{l}150- \\
300\end{array}$ & $\begin{array}{l}0- \\
150\end{array}$ & $>1500$ & $\begin{array}{c}\text { (Özşahin \& } \\
\text { Kaymaz, 2013; } \\
\text { Urfalı \& Eymen, } \\
\text { 2021) }\end{array}$ & 4 & 2.6 \\
\hline Eğim (\%) & $\begin{array}{c}0- \\
5\end{array}$ & $\begin{array}{l}5- \\
10\end{array}$ & $\begin{array}{c}10- \\
15\end{array}$ & $\begin{array}{c}15- \\
20\end{array}$ & $\begin{array}{c}20- \\
30\end{array}$ & $>30$ & $\begin{array}{c}\text { (Urfalı \& } \\
\text { Eymen, 2021) }\end{array}$ & 4 & 2.6 \\
\hline $\begin{array}{l}\text { Akarsulara } \\
\text { Uzaklık (m) }\end{array}$ & $>15000$ & $\begin{array}{l}12000- \\
15000\end{array}$ & $\begin{array}{l}9000- \\
12000\end{array}$ & $\begin{array}{c}6000- \\
9000\end{array}$ & $\begin{array}{c}3000- \\
6000\end{array}$ & $<3000$ & $\begin{array}{l}\text { (Aitzhanov, } \\
\text { 2016) }\end{array}$ & 5 & 1.3 \\
\hline $\begin{array}{l}\text { Göllere } \\
\text { Uzaklık (m) }\end{array}$ & $>15000$ & $\begin{array}{l}12000- \\
15000\end{array}$ & $\begin{array}{l}9000- \\
12000\end{array}$ & $\begin{array}{c}6000- \\
9000\end{array}$ & $\begin{array}{c}3000- \\
6000\end{array}$ & $<3000$ & $\begin{array}{l}\text { (Aitzhanov, } \\
\text { 2016) }\end{array}$ & 5 & 1.3 \\
\hline $\begin{array}{l}\text { Havaalanına } \\
\text { Uzaklık (m) }\end{array}$ & $>15000$ & $\begin{array}{c}12000- \\
15000\end{array}$ & $\begin{array}{l}9000- \\
12000\end{array}$ & $\begin{array}{c}6000- \\
9000\end{array}$ & $\begin{array}{c}3000- \\
6000\end{array}$ & $<3000$ & $\begin{array}{c}\text { (Bennui vd., } \\
\text { 2007) }\end{array}$ & 5 & 1.3 \\
\hline
\end{tabular}

Belirli bir alandaki ortalama rüzgâr hızı, ekonomik RES yatırımı için oldukça önemlidir. Hemen her çalışmada rüzgâr hızı faktörü ya direkt olarak kullanılır ya da rüzgâr hızı verisinden üretilen, kapasite faktörü veya güç yoğunluğu verilerine dönüştürülerek kullanılır. Rüzgâr hızı verisinin elde edilebilmesi için, T.C. Enerji ve Tabii Kaynaklar Bakanlığı Enerji İşleri Genel Müdürlüğü’nün hazırlamış olduğu REPA'da bulunan, Kocaeli ili 100 metre yükseklikteki yıllık ortalama rüzgâr hızı dağılım haritası (Şekil 3) resim formatında kaydedilip, CBS yazılım programı ortamına aktarıldıktan sonra, "georeferencing" işlemi ile, CBS yazılım programı üzerinde bulunan Kocaeli il haritası üzerine oturtulmuştur. Daha sonra resim üzerine yaklaşık 95000 nokta atılmıştır ve REPA'nın lejantına göre noktalara rüzgâr hızı değerleri el ile girilmiş̧ir. Bu işlem tamamlandıktan hemen sonra Ters Mesafe Ağılıklı Enterpolasyon (Inverse Distance Weighting, IDW) aracı yardımılla, noktalara girilen rüzgâr hızı değerleri kullanılarak 100 metre yükseklikteki rüzgâr hızı haritası elde edilmeye çalışılmıştır. RES yatırımı için uygun olmayan rüzgâr hızı pek çok çalışma için farklılık göstermektedir. Türkiye Rüzgâr Enerjisi Birliği (TÜREB) ile yapılan görüşmeler sonucu, 100 metrede 2.5-3 m/sn rüzgâr hızı RES sistemini çalıştırmaya yetecek bir rüzgâr rejimi olmasına rağmen, ekonomik RES yatırımı için rüzgâr hızının 5-6 m/sn değerlerinden başlayan bir rüzgâr rejimi olması gerektiği öğrenilmiştir. Ayrıca Baban ve Parry (2000) ve Özşahin ve Kaymaz (2013) çalışmaları da bu bilgiyi destekler niteliktedir. REPA'da bulunan bilgiye göre Kocaeli'nde en yüksek ortalama rüzgâr hız1 100 metrede $6.70 \mathrm{~m} / \mathrm{s}$ olduğundan, $5-6.7 \mathrm{~m} / \mathrm{s}$ arası 5 parçaya bölünerek sınıflandırılmış ve son derece uygun sınıfında $0.30 \mathrm{~m} / \mathrm{s}$, diğer sınıflarda $0.35 \mathrm{~m} / \mathrm{s}$ artış yapılmıştır. Ayrıca yine REPA'da bulunan bilgiye göre Kocaeli’nde 100 metrede en düşük rüzgâr hızı 2.23 m/s'dir. En yüksek rüzgâr hızı daha yüksek olan illerde daha farklı sınıflandırma yapılması mümkündür.

Korunan alanlara uzaklık faktörü birçok çalışmada parametre olarak alınmıştır. Korunan alanlar, T.C. Tarım ve Orman 
Bakanlığı Doğa Koruma ve Milli Parklar Genel Müdürlüğü (URL-8) internet sitesinden kontrol edilmiş ve Kocaeli’nde korunan alan olarak 8 tane tabiat parkı olduğu öğrenilerek haritası hazırlanmıştır. Korunan alanlara uzaklık faktörü doğal alanların zarar görmemesi veya yok olmaması, yaban hayatının zarar görmemesi, insanların bu tür alanlara her zaman ihtiyacı olduğu gerçeği vb. gibi nedenlerle çok önemlidir.

Rüzgâr türbinlerinin dönen kanatlarının kuşların gözünde bulanıklığa sebep olması sebebiyle türbinlere çarpma ihtimalleri oluşmaktadır. Bu durumu ortadan kaldırmak amacıyla RES'ler kuş göç yollarından belli bir uzaklığa inşa edilmelidir (Aydin vd., 2009). Ayrıca Kocaeli Karamürsel'de yapılması planlanan RES'in iptal sebeplerinden biri de mahkemenin görevlendirdiği bilirkişinin raporuna göre, kısmen kuş göç yolları üzerinde bulunmasıdır (URL-9). Bu nedenle kuş göç yollarına uzaklık faktörünün, ülkemiz için çok önemli bir kriter olduğu görülmektedir.

Trafo merkezleri enerjinin dönüştürülmesini sağlamaktadır. Enerji iletilirken kayıplar göz önüne alındığında trafo merkezlerine yakınlık önemli bir faktör haline gelmektedir (Urfalı \& Eymen, 2021). Trafo merkezlerine uzaklık haritası hazırlanırken dağıtım merkezi olan trafolar değil, Türkiye Elektrik İletim Anonim Şirketi’nin (TEİAŞ) mülkiyetinde olan ana trafo merkezleri göz önünde bulundurulmuştur.

Enerji nakil hatlarına uzaklık faktörüne birçok çalışmada önem verilmiş ve kullanılmıştır. RES'in pervane yarıçapıyla ilgili olarak enerji nakil hattıyla arasında bir mesafe olmalıdır. Genel olarak rüzgâr türbinlerinin pervane yarıçapı 100 metreyi geçmediğinden, 100 metre mesafe bırakılması doğru bir yaklaşım olacaktır (Sunak vd., 2015). Maliyet açısından ise, iletim hattına 10.000 metreden daha fazla uzaklık olması uygun olmayacaktır (Baban \& Parry, 2000). Enerji nakil hattına yakınlık, üretilen enerjinin hızlı ve az kayıpla aktarılabilmesi ve iletim hattına bağlanma maliyetini düşürmesi açısından önemlidir (Sunak vd., 2015). RES'lerin, Kocaeli'nin bağlı olduğu TEİAŞ 5. Genel Müdürlüğünden edinilen bilgiye göre, 34.5-180 kW arası orta gerilim hatlarına bağlanmasına onay verildiği öğrenilmiş ve bu hatlar kullanılmıştır.

Yerleşim alanlarına uzaklık faktörü, literatür taramaları kapsamında incelenen bütün çalışmalarda yer almaktadır. Yerleşim alanlarına uzaklık faktörü genel olarak sosyal kabulle ilgili bir durumdur. Rüzgâr türbinlerinin, gürültü, görsel ve peyzaj, gölge titreşimi veya ışı yansıması gibi etkilerinden dolayı yerleşim alanlarından uzakta konumlandırılmaları önemlidir (Sunak vd., 2015).

Karayollarına uzaklık faktörü ekonomik açıdan önemli olduğundan çoğu çalışmada değerlendirilmiştir. RES'lere rahat ve masrafsız ulaşım imkanlarının bulunduğu alanlar öncelikle tercih edilen yerlerdir. Çünkü rahat ve kolay ulaşım imkânı yoksa firmalar yol açtırmak zorundadır (Özşahin \& Kaymaz, 2013). Bununla birlikte görsel müdahaleyi azaltmak için karayollarından güvenli bir mesafede yerleştirilmelidir (Baban \& Parry, 2000).

Aktif fay hatlarına yakınlık arttıkça deprem etkisi de artacağından, fay hatlarına uzaklık kriteri önemli hale gelmektedir (Arca \& Çıtıroğlu, 2020). Aktif fay hatları, Maden Tetkik ve Arama Genel Müdürlügü’nün (MTA) internet sitesinde bulunan, yerbilimleri harita görüntüleyici ve çizim editörü (URL-6) üzerinden belirlenerek sayısallaştırılmıştır.

Yükseklik faktörü bazı çalışmalarda değerlendirmeye alınmıştır. Yükseklik haritası, sayısal yükseklik modeli (Digital Elevation Model, DEM) verisi olarak tanımlanmaktadır. USGS (United States Geological Survey) Earth Explorer (URL-7) sitesinden Mekik RADAR Topoğrafya Görevi (Shuttle RADAR Topography Mission, SRTM) yöntemiyle elde edilen DEM verisi, 1 ark-saniye (30 metre) çözünürlükte indirilmiştir. Rüzgâr hızı yükseltiye göre artma veya azalma eğilimi göstermektedir. Pratik olarak rüzgâr hızının her 150 metrede bir artış gösterdiği tespit edilmiştir. Bu yüzden yükselti faktörü de önem kazanmaktadır (Özşahin \& Kaymaz, 2013). 
Arazinin eğimi inşaat maliyetini etkiyebilecek bir faktördür (Atıcı vd., 2015). Bir yüzeyin dik eğimi vinçlerin ve kamyonların erişebilirliğini azaltır (Sunak vd., 2015). Rüzgâr türbinleri çok büyük yapılar olduğundan dolayı bunların taşınması ve kurulması çok zordur (Şimşek, 2020). Bu gibi sebeplerden ötürü eğim faktörü önem kazanmaktadır. Eğim haritası, yükseklik haritası kullanılarak yüzdelik olarak elde edilmiştir.

Akarsulara uzaklık faktörü çoğu çalışmada değerlendirilmektedir. Bazı çalışmalarda sadece akarsular kullanılırken, bazılarında ise akarsular ve göller, yüzey suları olarak bir bütün halinde değerlendirmeye alınmıştır. Akarsulara yakın alanlar yoğun arazi kullanımı, tarımsal faaliyet, bitki örtüsü ve yerleşim alanı olma gibi özelliklerinden dolayı rüzgâr türbini için uygun değildir (Arca \& Çıtıroğlu, 2020). Doğal alanları korumak önemli olduğundan bu faktör de değerlendirmeye alınması gereken bir kriter haline gelmektedir.

Akarsulara uzaklık kısmında bahsedildiği gibi, göllerin de kriterlere dahil edildiği bazı çalışmalarda akarsular ve göller beraber şekilde değerlendirilirken, göllere uzaklık faktörünün ayrıca değerlendirildiği Can ve Yücel (2019) çalışması, bu projede örnek alınmıştır. Göllere uzaklık faktörünün daha net belli olması ve veri türünün akarsulardan farklı olması nedeniyle bu yöntem tercih edilmiştir. Akarsular gibi gölleri de korumak ve yok olmalarını engellemek, kuraklığın giderek $\operatorname{arttığı~günümüz~dünyasında~çok~önemlidir.~}$

Havaalanına uzaklık faktörü bazı çalışmalarda kullanılmış ve uygun olmayan sınıfı için farklı değerlendirmeler yapılmıştır. 5431 sayılı kanunun 11. maddesi gereği, Sivil Havacılık Genel Müdürlüğü tarafından hazırlanan havaalanları çevresindeki yapılaşma kriterleri konulu belgeye göre (URL-10), havaalanı çevresinden itibaren 15000 metre boyunca devam eden yaklaşma ve kalkış-tırmanış yüzeyleri boyunca, havaalanlarından itibaren ilk 3000 metre içinde, insanların toplu halde bulunduğu hastane, otogar gibi yapılara ve uçuş güvenliğini tehlikeye düşürecek yükseklikte yapılara izin verilmemektedir. RES'ler yüksek yapılar olduğundan, uçuş güvenliği için ilk 3000 metre içinde yapımına onay verilmesi pek mümkün görülmemektedir. 3000 metreden sonraki kısımlar için Sivil Havacılık Genel Müdürlüğünden görüş alınmalıdır.

Faktörlerin, Tablo 8'de verildiği şekilde uygunluk sınıflarına ayrılmış haritaları Şekil 5'te gözükmektedir. 

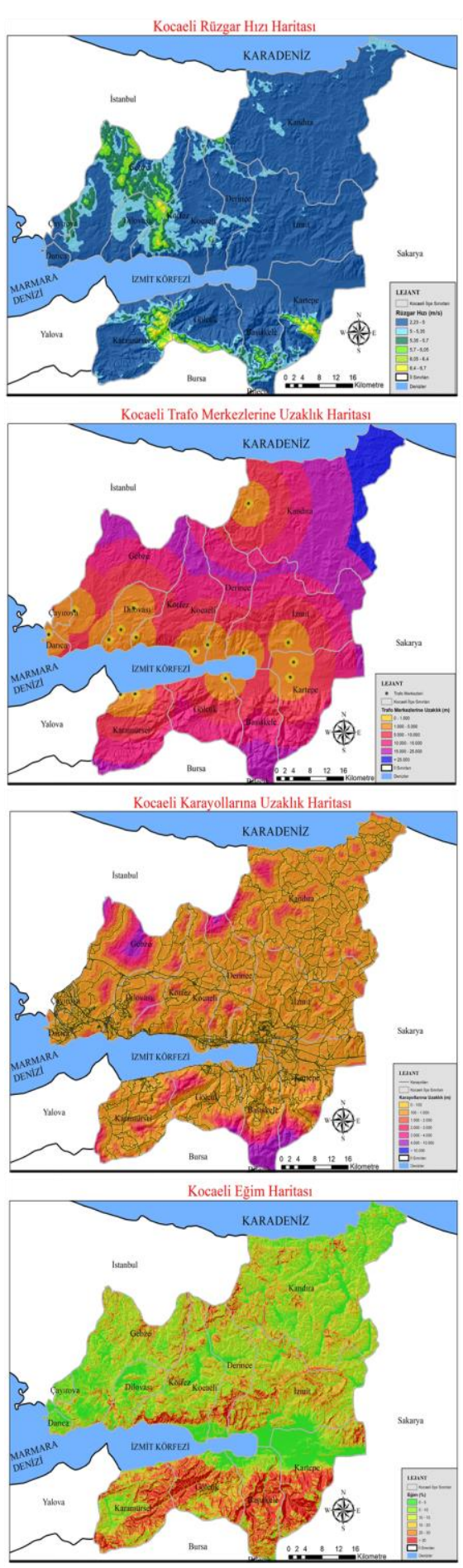
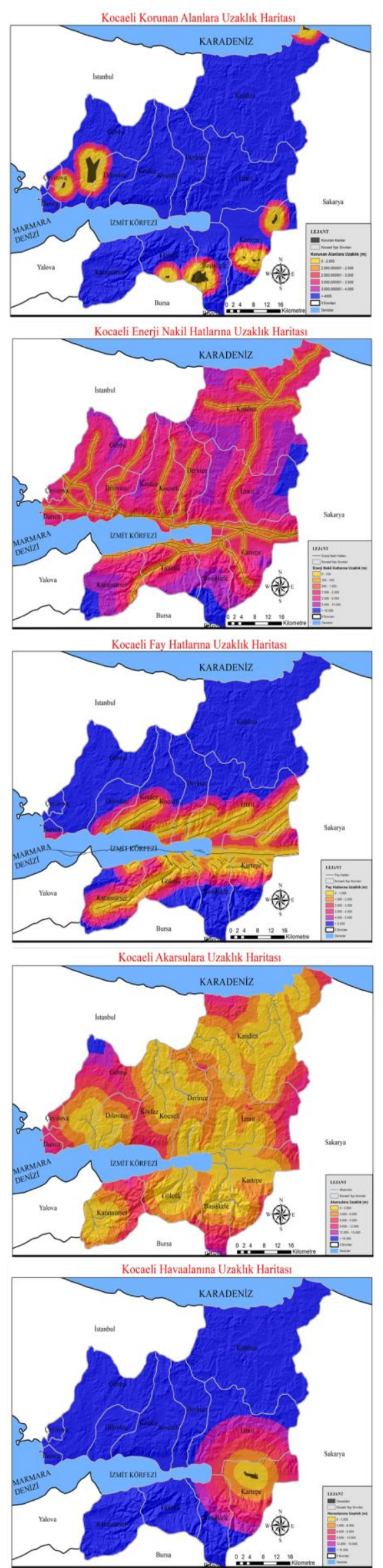
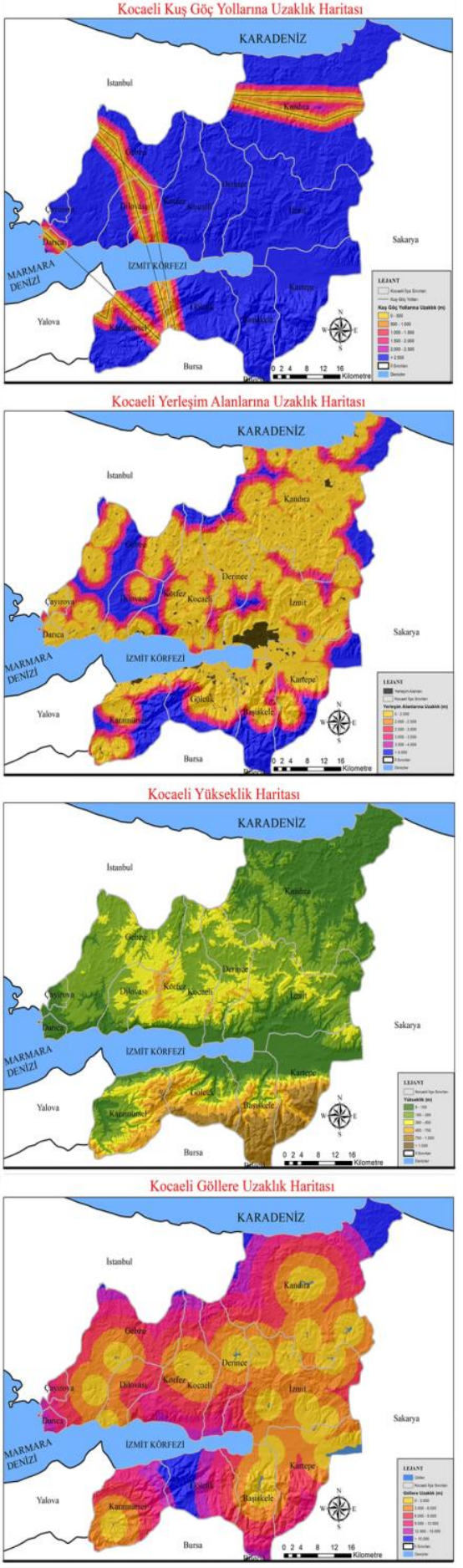

Şekil 5: Faktörlerin uygunluk sınıflarına ayrılmış haritaları 
RES kurulumu için belirlenen faktörlerin her biri ayrı ayrı incelendiğinde, faktörlerin uygun olmayan sınıflarında kalan alanların sonuç haritalarında bulunmaması gerektiği düşünülmüştür. Bu nedenle bir maskeleme haritası oluşturulmuştur (Şekil 6). Maskeleme haritası oluşturmak için öncelikle, faktörler uygunluk sınıfları tablosuna (Tablo 8) bağlı olarak, 1 (1, 2 , 3, 4, 5 puanlılar dahil olmak üzere tüm uygun olan alanlar) ve 0 (uygun olmayan alanlar (sadece 0 puan)) olmak üzere iki sınıfa bölünmüştür. Sonra veriler üst üste çakıştırılarak, Kocaeli ili için RES kurulabilir alanlar ve kurulamayacak alanlar olmak üzere harita üzerinde gösterilmiştir. $\mathrm{Bu}$ yöntem, bir faktör için bile, herhangi bir alan uygun olmayan sınıfında kalıyorsa, o alanı uygun olmayan sınıfa atayacaktır ve RES için uygun olmayan alanlar doğru bir şekilde belirlenebilecektir. Kocaeli ili RES uygunluk değerlendirme haritası Şekil 6 üzerinden incelenebilir.

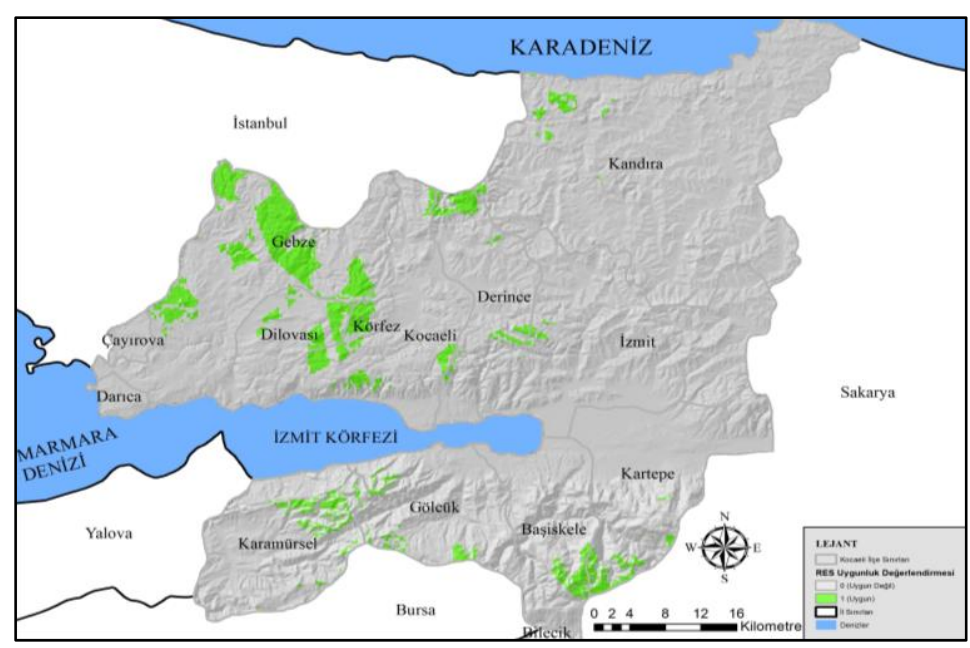

Şekil 6: Kocaeli ili RES için maske alanı haritası

Çalışmadaki faktörlerin birbirlerine göre ağırlıkları 2 farklı yöntem ile belirlenmiştir. İlk olarak faktörler AHY ile ağırlıklandırılmıştır. Buna göre Tablo 3'te faktörler birbirleri ile karşılaştırılarak, ara işlemler sonrasında Tablo 5 'te belirtilen ağırlık vektörleri belirlenmiştir. Bu ağırlık vektörleri kullanılarak faktörler çakıştırma işlemine sokulmuş ve Şekil 7'deki (sol) harita oluşturulmuştur. İkinci bir yöntem olarak faktör haritaları eşit olarak ağırlıklandırılmıştır. Bunun sonucunda elde edilen çakıştırma haritası Şekil 7 (sağ) üzerinden incelenebilir. Son olarak, RES için uygun olan alanların (Şekil 6), ne derece uygun olduğunun belirlenebilmesi için, iki yönteme göre elde edilen haritalar maske alanı haritası ile örtüştürülerek sonuç uygunluk haritaları elde edilmiştir (Şekil 8).

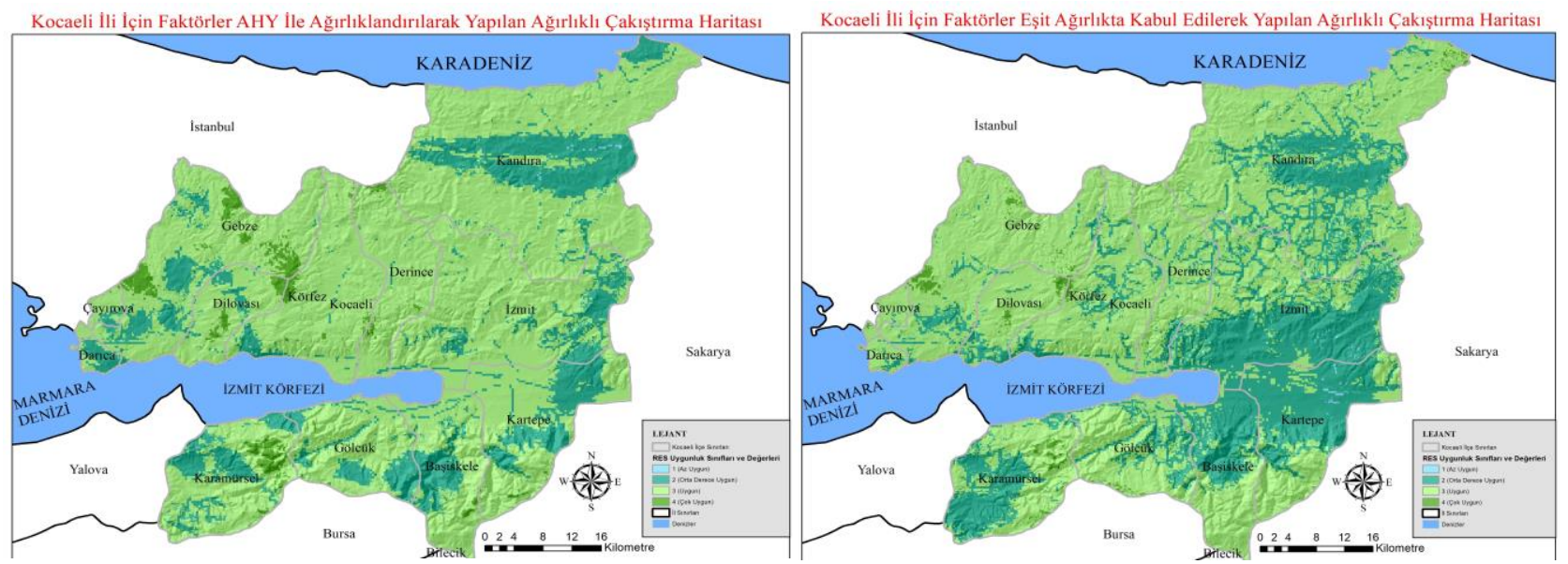

Şekil 7: (sol) Kocaeli ili için faktörler AHY ile ağırlıklandırılarak yapılan ağırlıklı çakıştırma haritası, (sağ) Kocaeli ili için faktörler eşit ağırlıkta kabul edilerek yapılan ağırıklı çakıştırma haritası 


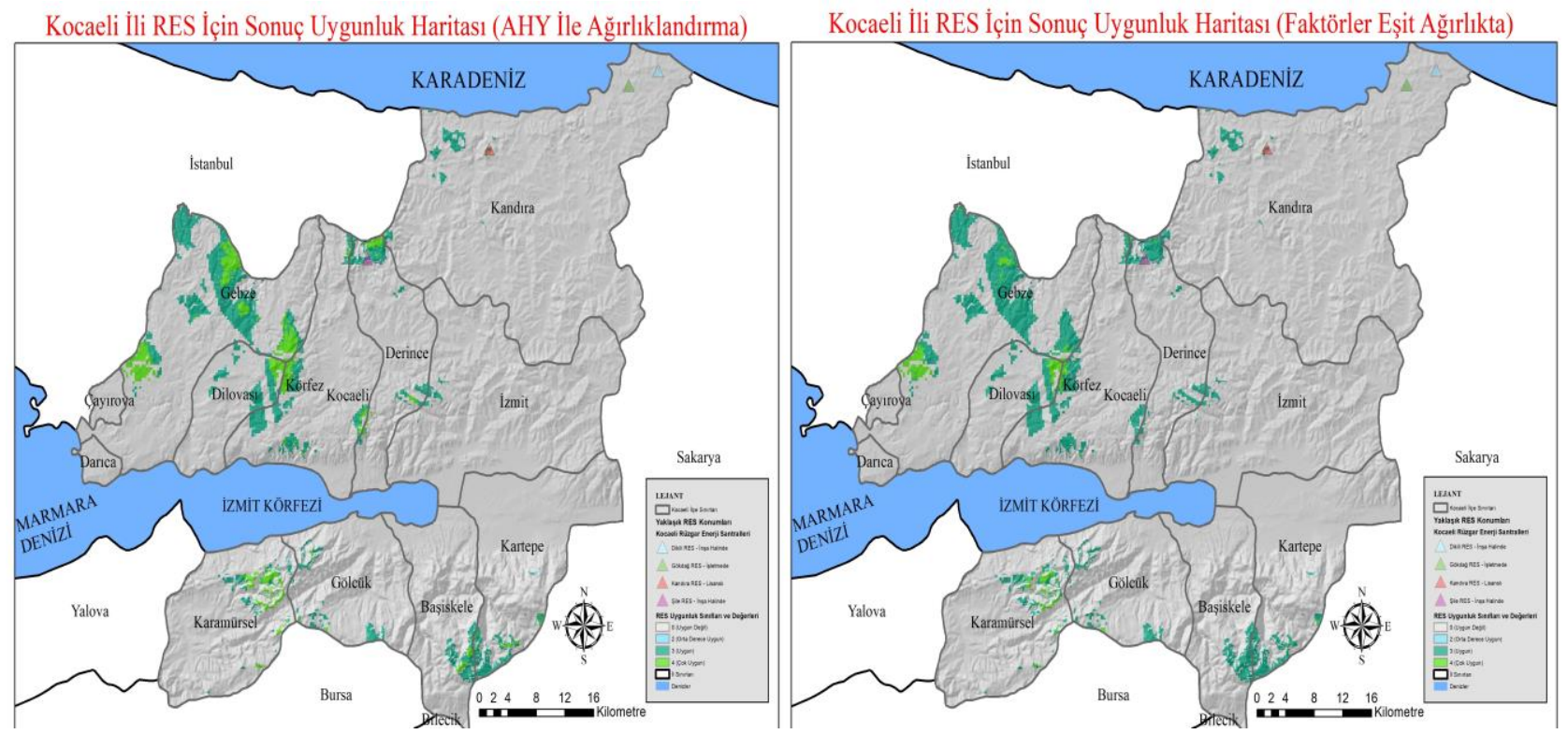

Şekil 8: (sol) Kocaeli ili RES için sonuç uygunluk haritası (AHY ile ağırıklandırma), (sağ) Kocaeli ili RES için sonuç uygunluk haritası (faktörler eşit ağırlıkta)

RES için sonuç uygunluk haritaları bulunduktan sonra, uygunluk sınıfları için kilometrekare $\left(\mathrm{km}^{2}\right)$ cinsinden alan çıkarımları yapılmıştır. AHY ile elde edilen sonuç uygunluk haritasının, uygunluk sınıflarına göre alan dağılımları ve faktörler eşit ağırlıkta kabul edilerek elde edilen sonuç uygunluk haritasının, uygunluk sınıflarına göre alan dağılımlarının karşılaştırılması Şekil 9'da sunulmuştur.

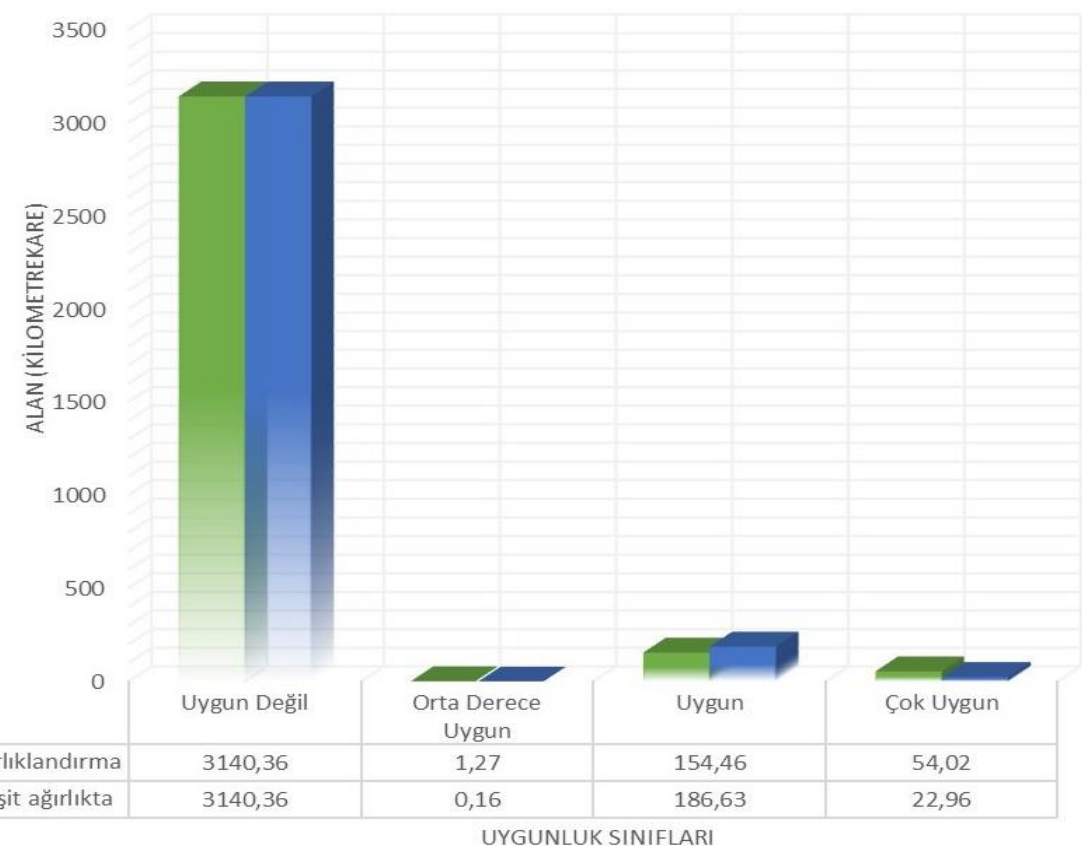

Şekil 9: Kocaeli ili RES için sonuç uygunluk alanlarının, faktörlerin AHY ile ağırlıklandırılması ve faktörlere eşit ağırlık verilmesi sonuçlarına göre karşılaştırılması

Uygunluk sınıfları alanlarının, her iki yöntemle bulunan sonuçlar için, ilçeler bazında dağılımı ise Tablo 9 üzerinden incelenebilir. 
Tablo 9: Kocaeli ili ilçeler bazında RES uygunluk sıııları alanları

\begin{tabular}{|c|c|c|c|c|c|c|c|c|}
\hline \multirow[b]{3}{*}{ İlçeler } & \multicolumn{8}{|c|}{ RES İçin Uygunluk Sınıfları Alanları $\left(\mathrm{km}^{2}\right)$} \\
\hline & \multicolumn{4}{|c|}{ AHY İle Ağırlıklandırma } & \multicolumn{4}{|c|}{ Faktörler Eșit Ağırlıkta } \\
\hline & $\begin{array}{c}\text { Çok } \\
\text { Uygun } \\
(4)\end{array}$ & $\begin{array}{c}\text { Uygun } \\
\text { (3) }\end{array}$ & $\begin{array}{c}\text { Orta } \\
\text { Derecede } \\
\text { Uygun } \\
(2)\end{array}$ & $\begin{array}{c}\text { Uygun } \\
\text { Değil } \\
(0)\end{array}$ & $\begin{array}{c}\text { Çok } \\
\text { Uygun } \\
(4)\end{array}$ & $\begin{array}{c}\text { Uygun } \\
\text { (3) }\end{array}$ & $\begin{array}{c}\text { Orta } \\
\text { Derecede } \\
\text { Uygun } \\
(2)\end{array}$ & $\begin{array}{c}\text { Uygun } \\
\text { Değil } \\
(0)\end{array}$ \\
\hline Başiskele & 1.72 & 9.03 & 0.06 & 194.31 & 0.02 & 10.80 & - & 194.31 \\
\hline Çayırova & - & - & - & 21.86 & - & - & - & 21.86 \\
\hline Darıca & - & - & - & 21.85 & - & - & - & 21.85 \\
\hline Derince & 3.69 & 11.72 & - & 181.27 & 0.25 & 15.21 & - & 181.27 \\
\hline Dilovası & 3.82 & 13.67 & 0.20 & 107.13 & 3.68 & 13.89 & - & 107.13 \\
\hline Gebze & 27.18 & 60.78 & 0.12 & 324.83 & 10.95 & 76.94 & - & 324.83 \\
\hline Gölcük & 0.68 & 7.40 & 0.21 & 204.43 & 0.52 & 7.94 & - & 204.43 \\
\hline İzmit & - & 2.48 & - & 475.28 & - & 2.48 & - & 475.28 \\
\hline Kandıra & 0.23 & 8.73 & 0.05 & 818.66 & 0.05 & 8.88 & - & 818.66 \\
\hline Karamürsel & 8.33 & 6.31 & 0.24 & 240.91 & 4.74 & 10.05 & - & 240.91 \\
\hline Kartepe & 1.42 & 11.49 & 0.18 & 285.08 & 0.29 & 12.81 & 0.16 & 285.08 \\
\hline Körfez & 6.95 & 22.85 & 0.21 & 264.75 & 2.46 & 27.63 & - & 264.75 \\
\hline Toplam: & 54.02 & 154.46 & 1.27 & 3140.36 & 22.96 & 186.63 & 0.16 & 3140.36 \\
\hline
\end{tabular}

\section{Sonuçlar ve Öneriler}

Bu çalışma kapsamında, dünya üzerinde her geçen gün artan enerji ihtiyacına karşı, başta ülkemiz ve tüm dünya ülkeleri tarafından önem verilen ve gelecek planlamalarında fazlaca yer alan, yenilenebilir enerji kaynaklarından rüzgâr enerjisi konusu ele alınmıştır. İlk olarak RES yer seçimini etkileyen faktörler tespit edilmiş ve ilgili faktör verileri çeşitli şekillerde elde edilmiştir. Elde edilen veriler ile gerekli analizlerin yapılabilmesi için CBS kullanılmıştır. Geçmiş̧e yapılan çalışmalar dikkatle taranarak faktör haritaları uygunluk sınıflarına bölünmüşsür. Uygunluk sınıflarına bölünen faktör haritaları ile, program üzerindeki çeşitli araçlar kullanılarak Kocaeli ili için RES uygunluk durumu haritası (maske alanı haritası) elde edilmiştir. Sonuç incelendiğinde, Kocaeli ilinin \%93.739'luk (3140.36 km²) alanı RES için uygun olmayan, \%6.261'lik $\left(209.75 \mathrm{~km}^{2}\right)$ alanı ise RES için uygun olan alan olarak çıkmıştır. Uygun alanlar ilçe bazında incelendiğinde, Gebze ilçesinin kuzey ve batı kısımlarında bazı alanlar, Gebze, Dilovası ve Körfez ilçelerinin sınırlarının birleştiği kısımdaki alan ve çevresi, Körfez ilçesinin güney, güneydoğu ve güneybatı kısımlarında bazı alanlar, Derince ilçesinin kuzey, güneydoğu ve güneybatı kısımlarındaki bazı alanlar, Kandıra ilçesinin kuzeybatı kısmında bazı alanlar, Başiskele ve Kartepe ilçesinin güneyde sınırlarının birleştiği kısımdaki alan ve çevresi, Karamürsel ilçesinin kuzeydoğu kısmında bazı alanlar, Gölcük ilçesinin kuzeybatı, güneybatı ve güneydoğu kısmında bulunan bazı olanlar, İzmit ilçesinin batı tarafinda ufak bir alan RES için uygun alanlar olarak görülmektedir. Çayırova ve Darıca ilçelerinde, RES için hiç uygun alan bulunmamaktadır.

Uygun olan alanların, uygunluk derecelerine göre sınıflandırılabilmesi için, ağırlıklı çakıştırma işlemi yapılmıştır. Bu aşamada ilk olarak, faktörleri birbirlerine karşı önceliklerine göre sıralayıp, çeşitli işlemlerden sonra ağırlıklarını belirleme yöntemi olan AHY kullanılarak elde edilen sonuçlara göre, \%93.739'luk (3140.36 km²) alanı RES için uygun olmayan (0 puan), \%0.038'lik (1.27 km²) alanı orta derecede uygun (2 puan), \%4.611'lik (154.46 km²) alanı uygun (3 puan), \%1.612'lik $\left(54.02 \mathrm{~km}^{2}\right)$ alanı çok uygun (4 puan) sınıfında çıkmıştır. Faktörler eşit ağırlıkta kabul edilerek elde edilen sonuçlara göre ise, \%93.739'luk (3140.36 km²) alanı RES için uygun olmayan (0 puan), \%0.005'lik ( $\left.0.16 \mathrm{~km}^{2}\right)$ alanı orta derecede uygun (2 puan), \%5.571'lik (186.63 km²) alanı uygun (3 puan), \%0.685'lik (22.96 km²) alanı çok uygun (4 puan) sınıfında çıkmıştır. Yapılan analizler sonucunda Kocaeli ilinde RES için, son derece uygun (5 puan) ve az uygun (1 puan) alan bulunmadığı görülmektedir. 
İki farklı sonuç haritası karşılaştırıldığında, faktörleri eşit ağırlıkta kabul etmek, her bir faktör farklı etkiler barındırdığından doğru bir yaklaşım değildir ve yanlış sonuçlara yol açabilir. Çünkü, değerlendiriciler veya eğer oluşturulduysa ülkelerin RES konusundaki yönetmelikleri, ekonomik, sosyal veya çevresel hassasiyetler bakımından, önemsediği olguyu ön planda tutarak, faktörlerin birbirleri karşısındaki önceliklerini mutlaka değerlendirecektir ve RES için yer seçimi bu önceliklere göre belirlenecektir. Faktörlerin öncelik durumları değerlendirilmeye başladığı anda ise, AHY, ELECTRE, VIKOR, TOPSIS, PROMETHEE ve Bulanık Kümeler gibi ÇKKA yöntemlerinin kullanılması, birçok faktörün etki ettiği bu tip çalışmalarda, doğru sonuca ulaşabilmek için büyük bir yardım sağlayacaktır. Literatürde yer alan, RES için en uygun yer araştırmasının yapıldığı çoğu çalışmada AHY kullanılmasına rağmen, ELECTRE (Atıcı vd., 2015) ve Bulanık Kümeler (Aydin vd., 2009; Latinopoulos \& Kechagia, 2015) yöntemlerinin kullanıldığg çalışmalar da mevcuttur. Bu çalışmada ÇKKA yöntemlerinden AHY'nin kullanılmasının sebebi, anlaması ve uygulaması kolay olması, hızlı bir şekilde çözüme gitmesi, kendi içinde kontrol mekanizması olması ve birçok çalışmada tercih edilmiş olmasıdır.

Çalışmada ayrıca, Kocaeli'nde bulunan RES’lerin yaklaşık konumları sonuç uygunluk haritaları üzerinde belirtilerek, değerlendirme analizi yapılmıştır. Buna göre Kandıra ve Şile RES uygun alanda, Dikili ve Gökdağ RES ise uygun olmayan alanda çıkmıştır. Dikili ve Gökdağ RES'in uygun olmayan alanda çıkmasının sebebi, bir veya birden çok faktörün, geçmiş çalışmalardan yola çıkılarak belirlenen, uygun olmayan (0 puan) sınıfında bulunmasıdır. Farklı sınıflandırmalar yaparak, farklı sonuçlar elde etmek mümkündür. RES için faktörler ve uygunluk sınıfları için ülkemizde bir yönetmelik bulunmamaktadır. Konunun uzmanları ile yapılan görüşmeler sonucunda, birçok faktörün etkisinin bulunduğu böyle bir projede, keskin sınırlar belirleyebilmenin pek mümkün olmadığı öğrenilmiştir. Bu tür projelerde yatırımcının, araştırmalarını yapıp, istenilen raporları hazırlayarak ilgili kurumlara başvurduğunu ve kurumların incelemelerini tamamlayıp karar verdiği öğrenilmiştir.

CBS ve AHY, bu ve bunun gibi birçok çalışmada kullanılabilecek etkili bir yöntemdir. Çalışmada kullanılan faktörler arttırılarak daha kapsamlı sonuçlar elde edilebilmesi mümkündür. Kocaeli ili RES için yer seçimi analizi yapılan bu çalışmada, rüzgâr enerjisi için yüksek derecede olmasa da potansiyeli olan bir il olduğu sonucu elde edilmiştir. Halihazırda ilde bulunan RES'ler bu sonucu desteklemektedir. Bu potansiyel kullanılıp, en etkili şekilde değerlendirilmelidir. Çalışmamız, RES yer seçimi sürecinde, doğru ve ekonomik yatırımın yapılabilmesi için, CBS ve AHY kullanılarak başarılı sonuçların elde edilebileceğini göstermektedir.

\section{Teşekkür}

Lisans derecesi bitirme projesinin makale formatına dönüştürüldüğü bu çalışmada, çalışma boyunca değerli zamanını ayırarak bizi motive eden, yol gösteren ve destek sağlayan saygıdeğer hocamız Prof. Dr. Arzu Erener'e, gerekli bazı verilere ulaşmamızda bize kolaylık sağladıkları için Piri1513 Coğrafi Bilgi Sistemleri şirketi yetkililerine ve konunun uzmanı kişilerin görüşlerine ihtiyacımız olduğu durumlarda, bize bilgi, tecrübe ve görüşlerini aktaran TÜREB Kamu İşleri Yöneticisi Aytunç Bey’e ve çalışma arkadaşlarına teşekkür ederiz.

\section{Yazar Katkısı}

Serdar Ekiz: Fikir, Tasarım, Literatür Taraması, Veri Toplama ve İşleme, Analiz ve Yorumlama, Yazım. Ahmet Şirin: Fikir, Tasarım, Veri Toplama ve İşleme, Yazım. Arzu Erener: Tez ve Makale Denetimi, Danışmanlık. 


\section{Çıkar Çatışması Beyanı}

Yazarlar, bu çalışmada bilinen ilgili herhangi bir finansal veya finansal olmayan çıkar çatışması olmadığını beyan ederler.

\section{Kaynaklar}

Aitzhanov, C. (2016). Site Selection Technique For Wind Turbine Power Plants Utilizing Geographical Information Systems (GIS) and Analytical Hierarchy Process (AHP) (Yüksek Lisans Tezi). İstanbul Teknik Üniversitesi, Fen Bilimleri Enstitüsü, İstanbul.

Arca, D., \& Çıtıroğlu, H. K. (2020). Rüzgâr Enerjisi Santral (RES) Yapım Yerlerinin CBS Dayalı Çok Kriterli Karar Analizi ile Belirlenmesi: Yenice İlçesi (KARABÜK) Örneği. Karaelmas Fen ve Mühendislik Dergisi, 10(2), 168-176.

Artun, O. (2020). Determination of the Suitable Areas for The Investment of the Wind Energy Plants (WEP) in Osmaniye Using Geographic Information Systems (GIS) and Analytical Hierarchy Process (AHP). European Journal of Science and Technology, 20, 196-205.

Atıcı, K. B., Şimşek, A. B., Ulucan, A., \& Tosun M. U. (2015). A GIS-based Multiple Criteria Decision Analysis approach for wind power plant site selection. Utilities Policy, 37, 86-96.

Aydin, N. Y., Kentel, E., \& Duzgun, S. (2009). GIS-based environmental assessment of wind energy systems for spatial planning: A case study from Western Turkey. Renewable and Sustainable Energy Reviews, 14(1), 364-373.

Baban, S. M. J., \& Parry, T. (2000). Developing and Applying A GIS-Assisted Approach to Locating Wind Farms in The UK. Renewable Energy, 24(1), 59-71.

Bennui, A., Rattanamanee, P., Puetpaiboon, U., Phukpattaranont, P., \& Chetpattananondh, K. (2007). Site Selection For Large Wind Turbine Using GIS. PSU-UNS International Conference on Engineering and Environment-ICEE-2007, Phuket, Thaliand.

Can, G., \& Yücel, M. A. (2019). Coğrafi Bilgi Sistemleri ve Analitik Hiyerarşi Prosesi Kullanarak Rüzgâr Enerji Santralleri İçin Yer Tespiti. TMMOB Harita ve Kadastro Mühendisleri Odası, 17. Türkiye Harita Bilimsel ve Teknik Kurultayl, 25-27 Nisan 2019, Ankara.

Demirci, A. (2019). Kuruluş Yeri Seçiminde Analitik Hiyerarşik Süreç Yöntemi: Sağlık Kurumlarında Bir Uygulama. Uluslararası İktisadi ve İdari Bilimler Dergisi, 5(1), 39-55.

Güler, D. (2016). Analitik Hiyerarşi Yöntemi ve Coğrafi Bilgi Sistemleri ile Alternatif Katı Atık Düzenli Depolama Alanı Yer Seçimi: İstanbul İli Örneği (Yüksek Lisans Tezi). İstanbul Teknik Üniversitesi, Fen Bilimleri Enstitüsü, İstanbul.

Harker, P. T. (1989). The Art and Science of Decision Making: Analytic Hierarchy Process. In: The Analytic Hierarchy Process, 3-36, Berlin, Germany.

Koç, A., Yağlı, H., Koç, Y., \& Uğurlu, İ. (2018). Dünyada ve Türkiye'de Enerji Görünümünün Genel Değerlendirilmesi. Mühendis ve Makina, 59(692), 86-114.

Latinopoulos, D., \& Kechagia K. (2015). A GIS-Based Multi-Criteria Evaluation For Wind Farm Site Selection. A Regional Scale Application in Greece. Renewable Energy, 78, 550-560.

Memduhoğlu, A., Özmen, G., Göyçek, G., \& Kılıç, F. (2014). Rüzgâr Türbini Kurulacak Alanların CBS - Çok Ölçütlü Karar Analizi Kullanılarak Belirlenmesi: Davutpaşa Kampüsü. V. Uzaktan Algılama ve Coğrafi Bilgi Sistemleri Sempozyumu (UZAL-CBS 2014), 1417 Ekim, İstanbul.

Özşahin, E., \& Kaymaz, Ç. K. (2013). Rüzgâr Enerji Santrallerinin (RES) Yapım Yeri Seçimi Üzerine Bir CBS Analizi: Hatay Örneği. TÜBAV Bilim Dergisi, 6(2), 1-18.

Pala, O. (2013). Bulanık Mantık ve Çok Kriterli Karar Verme Uygulaması (Yüksek Lisans Tezi). Dokuz Eylül Üniversitesi, Sosyal Bilimler Enstitüsü, İzmir.

Saat, M. (2000). Çok Amaçlı Karar Vermede Bir Yaklaşım: Analitik Hiyerarşi Yöntemi. Gazi Üniversitesi İktisadi ve İdari Bilimler Fakültesi Dergisi, 2(2), 149-162.

Saaty, T. L. (1986). Axiomatic Foundation of The Analytic Hierarchy Process. Management Science, 32(7), 841-855.

Saaty, T. L. (1990). How to Make A Decision: The Analytic Hierarchy Process. European Journal of Operational Research, 48, 9-26.

Saaty, T. L. (1994). How to Make A Decision: The Analytic Hierarchy Process. Interfaces, 24(6), 19-43.

Saaty, T. L., \& Vargas, L. G. (2001). The Decision by The US Congress on China's Trade Status: A Multicriteria Analysis. In: Models, Methods, Concepts \& Applications of the Analytic Hierarchy Process, (s.305-317). 
Sunak, Y., Höfer, T., Siddıque, H., Madlener, R., \& Doncker, R. W. D. (2015). A GIS-Based Decision Support System for The Optimal Siting of Wind Farm Projects. E.ON Energy Research Center Series, 7(2), RWTH Aachen University, Germany.

Şimşek, G. (2020). Modelling Site Selection Process For Wind Power Plants Through Free and Open Source GIS (Yüksek Lisans Tezi). İstanbul Teknik Üniversitesi, Fen Bilimleri Enstitüsü, İstanbul.

TÜREB (2020). Türkiye Rüzgâr Santralleri Atlası. Ocak-2020, Ankara.

Tütek, H., Gümüşoğlu, Ş., \& Özdemir, A. (2012). Sayısal Yöntemler: Yönetsel Yaklaşım. Beta Basın Yayım Dağıtım, İstanbul.

Urfalı, T., \& Eymen, A. (2021). CBS ve AHP Yöntemi Yardımıyla Kayseri İli Örneğinde Rüzgâr Enerji Santrallerinin Yer Seçimi. Geomatik Dergisi, 6(3), 227-237.

Yaralığlu, K. (2004). Uygulamada Karar Destek Yöntemleri. İzmir Ofset, İzmir.

URL-1: https://ekolojist.net/turkiyede-ruzgar-enerjisi/ (Erişim Tarihi: 19 Nisan 2021).

URL-2: https://enerji.gov.tr/eigm-yenilenebilir-enerji-kaynaklar-ruzgar (Erişim Tarihi: 19 Nisan 2021).

URL-3: https://repa.enerji.gov.tr/REPA/ (Erişim Tarihi: 28 Nisan 2021).

URL-4: www.openstreetmap.org/export\#map=9/40.7618/29.6603 (Erişim Tarihi: 28 Nisan 2021).

URL-5: http://birdmap.5dvision.ee/EN/2021/spring/?line=1\&track=0\&speed=1 (Erişim Tarihi: 28 Nisan 2021).

URL-6: http://yerbilimleri.mta.gov.tr/anasayfa.aspx (Erişim Tarihi: 28 Nisan 2021).

URL-7: https://earthexplorer.usgs.gov/ (Erişim Tarihi: 28 Nisan 2021).

URL-8: https://www.tarimorman.gov.tr/DKMP (Erişim Tarihi: 28 Nisan 2021).

URL-9: https://www.ozgurkocaeli.com.tr/haber/6651270/mahkeme-karamursel-res-projesini-durdurdu (Erişim Tarihi: 28 Nisan 2021).

URL-10: http://web.shgm.gov.tr/doc5/2549-7.pdf (Erişim Tarihi: 28 Nisan 2021). 